PNL-3105

UC-71

\title{
Pacific Northwest Laboratory (PNL) Spent Fuel Transportation and Handling Facility Models
}

W. B. Andrews

J. C. Bower

R. A. Burnett

R. L. Engel

C. W. Rolland

September 1979

Prepared for the U.S. Department of Energy under Contract EY-76-C-06-1830

Pacific Northwest Laboratory Operated for the U.S. Department of Energy by Battelle Memorial Institute 


\title{
NOTICE
}

This report was prepared as an account of work sponsored by the United States Government. Neither the United States nor the Department of Energy, nor any of their employees, nor any of their contractors, subcontractors, or their employees, makes any warranty, express or implied, or assumes any legal liability or responsibility for the accuracy, completeness or usefulness of any information, apparatus, product or process disclosed, or represents that its use would not infringe privately owned rights.

The views, opinions and conclusions contained in this report are those of the contractor and do not necessarily represent those of the United States Government or the United States Department of Energy.

\author{
PACIFIC NORTHWEST LABORATORY \\ operated by \\ BATTELLE \\ for the \\ UNITED STATES DEPARTMENT OF ENERGY \\ Under Contract EY-76-C-06-1830
}

\author{
Printed in the United States of America \\ Available from \\ National Technical Information Service \\ United States Department of Commerce \\ 5285 Port Royal Road \\ Springfield, Virginia 22151
}

Price: Printed Copy $\mathbf{S}$

$\because$ Microfiche $\$ 3.00$

NTIS

-Pages Selling Price

$001-025 \quad \$ 4.00$

026-050 $\quad \$ 4.50$

$051-075 \quad 55.25$

$076-100 \quad \$ 6.00$

$101-125 \quad \$ 6.50$

$126-150 \quad \$ 7.25$

$151-175=\$ 8.00$

$176-200 \quad \$ 9.00$

$201-225 \quad \$ 9.25$

$226-250 \quad \$ 9.50$

$251-275 \quad \$ 10.75$

$276-300 \quad 511.00$ 
PACIFIC NORTHWEST LABORATORY (PNL)

SPENT FUEL TRANSPORTATION AND

HANDLING FACILITY MODELS

\author{
W. B. Andrews \\ J. C. Bower \\ R. A. Burnett \\ R. L. Enge 1 \\ C. W. Rolland
}

September, 1979

Prepared for U. S. Department of Energy under Contract EY-76-C-06-1830

Pacific Northwest Laboratory

Richland, Washington 99352 
.

$\therefore$

.

. 


\section{CONTENTS}

1.0 SUMMARY . . . . . . . . . . . . $1-1$

2.0 INTRODUCTION . . . . . . . . . . . . . . . . . . . . .

3.0 PACIFIC NORTHWEST LABORATORY SITE EVALUATION MODEL . . . •

3.1 SPENT FUEL TRANSPORTATION SYSTEM . . . . . . . . 3-1

3.1.1 Spent Fuel Handing Facilities . . . . . 3-2

3.1.2 Spent Fuel Transportation Equipment . . . . 3-4

3.2 LOGISTICS MODELING . . . . . . . . . . . . 3-6

3.2.1 Model Description. . . . . . . . . . . $3-7$

3.2.2 Computer System Structure and Operation . . 3-12

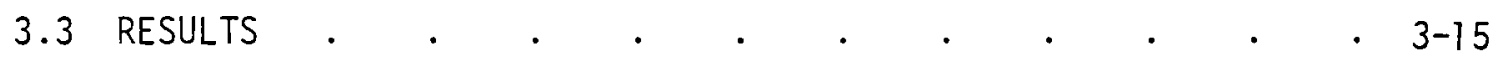

4.0 PACIFIC NORTHWEST LABORATORY FACILITY SIMULATION MODEL . . . 4-1

APPENDIX A - PACIFIC NORTHWEST LABORATORY SITE

EVALUATION MODEL USER'S GUIDE . . . . . . . A-1

APPENDIX B - SAMPLE SITE EVALUATION MODEL INPUT AND OUTPUT . . •

APPENDIX C - LIST OF NUCLEAR POWER FACILITIES INCLUDED IN THE SITE EVALUATION MODEL DATA BASE . . . . . . . . . C- 1 

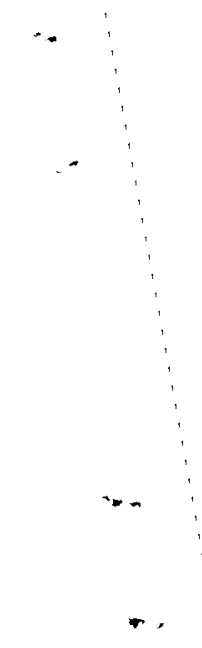


\subsection{SUMMARY}

Pacific Northwest Laboratory $(P N L)^{(a)}$ has conducted a spent fuel logistics study in support of the Department of Energy's program to design, license and construct facilities to prepare spent unreprocessed fuel from commercial light-water reactors for eventual storage in geological repositories. The objectives of this logistics study were 1) to provide quantitative information on existing and required transportation systems to assist in siting and designing spent fuel storage and/or handling and packaging facilities and 2) to develop a methodology to evaluate alternative spent fuel storage and handling policies. Two computerized logistics models have been developed for use in these studies.

The site evaluation model was developed to calculate logistics parameters for shipments of spent fuel from existing and planned nuclear power plants to spent fuel storage/handling facilities. The model was used to study the effects of changes in the location of fuel storage/handling facilities or geologic repositories and to changes in policy or regulation on spent fuel logistics. Examples of policy issues which can be examined include maintenance of a fuel care storage reserve at nuclear power plants, reracking fuel storage, basic and intra-utility fuel shipments.

The model can analyze spent fuel storage or handling strategies with up to four storage/handling facility locations. Interim storage of fuel at a commercial Away From Reactor (AFR) storage facility before transfer to government storage/handling facilities may also be considered to account for any required fuel shipments before government facilities become available. Eventual transfer to the spent fuel from the storage/handling facilities to a permanent disposal facility is included in the model. Analyses can be performed with the model for AFR's, government storage/handling facilities and repositories located anywhere in the continental U.S.

Input data for the site evaluation model and problem assumptions are supplied by the user through an interactive computer graphics terminal. Basic information on the model and the system it is designed to analyze are presented to the user along with a series of questions that he answers to define (a) Operated by Battelle Memorial Institute. 
the problem under consideration. The information presented to the user includes a map of the United States showing the location of all light water reactors currently operating, under construction, or planned in the U.S. through 1990. The user can enter the locations of the ARF, spent fuel storage/ handling facilities and repository to be considered in the problem on this map using a light pen. Alternatively a latitude and longitude may be specified for any of the facilities. A description of the fuel storage strategy, spent fuel shipping cask fleet, and transportation costs are also input. Default values are available for most of these parameters.

The solution algorithm used in this model is a highly-efficient, minimumcost primal network algorithm. It constructs a spent fuel distribution system for the problem under consideration and calculates a shipment and storage schedule such that the total spent fuel transportation and storage costs are minimized. The solution algorithm generates a spent fuel shipping schedule for each reactor (or reactor group) that will have fuel available for shipment during the time period being analyzed in the problem. It selects the transport mode, destination (if more than one spent fuel storage/handling facility are being considered) and amount of fuel shipped each year. Annual shipping and receiving schedules for the AFR storage facility, the spent fuel storage/ handiing facility and the repository are also determined. The algorithm makes decisions on when and where fuel is shipped based on minimzing costs for the total system within the constraints of storage capacities at the nuclear power plants and storage and receiving capacities at the AFR storage facility, spent fuel storage/handing facilities, and the repository.

Two studies of spent fuel handling facility and spent fuel disposal facility siting have been completed. The first postulates a single spent fuel handling facility located at any of six Department of Energy laboratory sites. In general, eastern sites require about half the shipping fleet and cost of a western site. A site in the west (Hanford) could require 14 rail and 82 truck casks by 1983 and grow to 29 and 161 casks, respectively, by 1990. Annual transportation charges to the Hanford site would total $\$ 25$ million in 1983 and grow to $\$ 51$ million in 1990. 
The second study examined siting strategies with the spent fuel repository relative to the spent fuel handling facility. Colocation of a spent fuel handling facility and a spent fuel repository at an eastern site minimizes transportation requirements. A somewhat higher cost results from handiing and repository facilities located at separate sites in the east. Locating the handling facility on the opposite side of the country from the repository or siting both facilities in the west results in the highest total cost. Short term (nuclear power plant to handling facility) transportation costs are minimized for a spent fuel handling facility located in the west.

A second model to conduct storage/handling facility simulations was developed to provide quantitative logistics information to aid in the design of these facilities. The model can be useful in optimizing the design and operation of the spent fuel handling/storage facility; in analyzing the effects of changes in the transportation system on the efficiency of operating the spent fuel handling/storage facility; and in analyzing the effects of facility design changes on the transportation system.

The simulation is a general methodology that can be applied to analysis of the performance of any previously defined system. With realistic input parameters it may be possible to infer behavior of the system from observations of the model behavior. Flexibility in the model permits alteration of system parameters to study the impact of changes on the operation of the system. In this way, a series of "what if?" questions may be used to gain understanding about the operation of the system.

The site evaluation and facility simulation models can be combined to obtain information relevant to the entire transportation/spent fuel handling facility system. Changes in transportation policy or equipment may directly effect fuel receiving facility design requirements. Conversely a design change in the receiving facility that changes cask turnaround times or facility throughput will hanve an effect on transportation hardware requirements and costs. The insights gained by the use of these "systems approach" models during the design and planning of spent fuel transportation systems could contribute to the development of a more efficient spent fuel handling industry. 


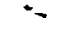

3

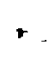




\subsection{INTRODUCTION}

Transportation of spent fuel is required to assure continued operation of nuclear power facilities. Fuel must be moved first to storage facilities and then ultimately to a facility designed to use or dispose of the fuel. PNL has developed analytical tools and information to assess spent fuel shipping system requirements for alternatives in reactor storage strategies, fuel management policy and fuel storage facility locations and design. This report describes these tools and discusses completed parametric studies.

\subsection{BACKGROUND}

In October 1976 and April 1977, presidential policy statements on nuclear energy were announced which included the continued use of light water reactors (LWR) to produce electrical power and the indefinite postponement of spent fuel reprocessing. Extended retrievable storage was adopted as a means of maintaining the fuel until a spent fuel management option is selected. These options include terminal disposal of spent fuel, full LWR recycle of fissile materials and LWR uranium recycle with plutonium used to fuel fast breeder reactors.

Several methods of retrievable spent fuel storage are currentiy available or under development. Water basin storage of fuel elements is currently used to store short cooled fuel in an "as discharged" condition. Uncertainties in the feasibility of water storage for periods in excess of 25 years and the need for an additional containment barrier to protect the fuel during disposal facility operations has led to the development of concepts for surface and near-surface dry storage of packaged spent fuel. The Commercial Waste and Spent Fuel Packaging Program (CWSFPP) was initiated by the Department of Energy to quantify options in spent fuel packaging and surface storage.

\subsection{PNL SPENT FUEL LOGISTICS}

The objectives of the PNL Spent Fuel Logistics task in the CWSFP program were to determine transportation system capabilities to move all spent fuel available from nuclear power plants to offsite storage locations through 
the 1990's and to provide information useful in the development of a cost efficient transportation and spent fuel storage system. After careful study of the spent fuel system, it was determined that nuclear power plant and fuel transport container designs are fixed and that cost efficiency depends on the storage facility design and location. Transportation system requirements are dependent on the amount of fuel to be shipped and the locations of storage facilities. A review of available modeling techniques led to the conclusion that two separate analytical tools would be required.

Nuclear Power Plant fuel storage strategies and operating policies can greatly influence the amount of fuel available for transport in the 1980's and 1990's. Changes in the amount of available fuel creates a variable need for spent fuel shipping equipment, storage facilities, and funding to both build and operate this equipment. Spent Fuel Handling and Packaging Facility (SFHPF) locations and capacities also have an effect on required transportation equipment and transportation cost. These two areas of alternatives are studied using the PNL Site Evaluation Model. Model development and results of studies done to date are presented in Section 3 of this report.

The ability of a spent fuel receiving facility to efficiently unload, empty and offload spent fuel shipping containers is important in determining the number of containers that are required. Transients in both the package receiving rates and facility unloading rates must also be considered to assure adequate surge storage in the spent fuel receiving facility design. The PNL Facility Simulation Model can be used to study alternatives in facility operating policies and design for their effect on transportation equipment requirements. Section 4.0 presents a description of the model and how it has been applied to a spent fuel receiving facility. 


\subsection{PACIFIC NORTHWEST LABORATORY \\ SITE EVALUATION MODEL}

The site evaluation model was developed to provide quantitative information on the logistics parameters for shipments of spent fuel from existing and planned nuclear power plants to spent fuel storage/handling facilities. The model is useful to estimate the effect on cost and logistics parameters of changes in the locations of storage and handling facilities or geologic repositories and in evaluating the effect of policy or regulation changes on spent fuel logistics.

This section describes the spent fuel transportation system, modeling assumptions, and the solution methodology used to obtain spent fuel shipment schedules, optimized on transportation costs, for multiple SFHP facilities at variable locations in the U.S. Results of studies of SFHP facility siting options and spent fuel storage strategies are also reported.

\subsection{SPENT FUEL TRANSPORTATION SYSTEM}

The spent fuel transportation system considered in this study consists of spent fuel facilities linked by a finite system of truck and rail transportation equipment and transportation corridors.

This section describes the spent fuel facilities and their functions relative to the spent fuel transportation system. Spent fuel transport packages, their costs, and transportation charges are also described.

The four types of spent fuel facilities considered in the analys is are shown in Figure 1. Spent fuel is generated and stored at nuclear power plants. After the heat generation rate in the fuel has decreased to acceptable levels through radioactive decay, the fuel is transported by truck or train to either commercial or government storage/handling facilities. Commercial storage is considered short term and the fuel stored there is eventually reshipped to a government facility. From the government facility, fuel will be moved by rail to either a disposal or reprocessing facility. 


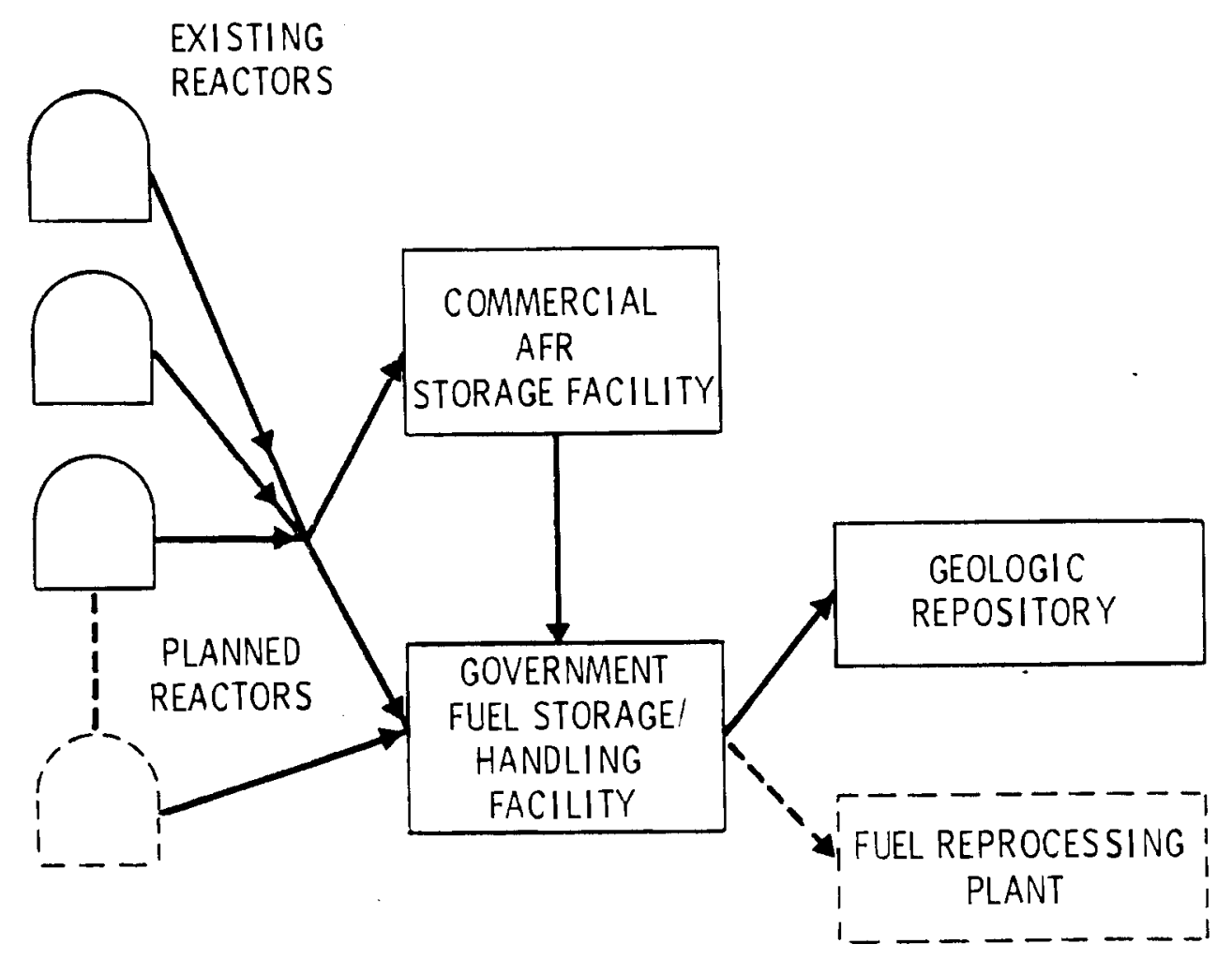

FIGURE 1. Spent Fuel Shipping System

\subsubsection{Spent Fuel Handling Facilities}

A11 nuclear power plants that are currently operating, under construction, or planned through 1990 were considered in the transportation system. A listing of plants considered in this study is included in Appendix C. Specific information on each nuclear power facility is available to describe plant location, capacities, and spent fuel handling capabilities. (1) Annual fuel discharge schedules, the amount of fuel per discharge, fuel storage basin capacities and the amount of fuel in storage at the beginning of the study period, describe the potential transportation system requirements.

Nuclear power plant operators have several fuel strategies available assuming that fuel discharge schedules are fixed. The incremental cost of fuel storage at a reactor site was considered to be small, so that operators have incentive to maintain basins as full as possible. One method of 
maximizing basin capacities is to use high density fuel storage racks. Many nuclear power plant fuel storage pools have had new fuel storage racks installed to take avantage of this option. Reactor operators maintain a full core storage reserve in case the reactor core must be removed for maintenance. Although not desirable, this policy could be waived on a short-term basis to obtain additional storage capacity, particularly if offsite storage is unavailable.

When fuel storage pools are ful1, with or without a storage reserve, offsite fuel shipments are required. Several potential destinations exist in the spent fuel transportation system. Shipment of fuel to another reactor of similar design may be practiced if space is available and economical transportation is possible. For this study this was considered a possibility only for intra-utility shipments between reactors of similar fuel design. These intra-utility shipments were considered only for their effect on the amount of fuel available for shipment from the nuclear power plants to government storage/handling facilities. Logistics and costs were not calculated for this transportation link.

Commercial away from reactor (AFR) facilities are a possibility for offsite fuel shipments. An AFR fuel storage facility was considered in this study to utilize the water basin storage concept. A facility located in Morris, Illinois, owned by the General Electric Corporation is of this type and has fuel received from offsite currently in storage. In this study, commercial AFR facilities were assumed available and capable of handing fuel required to be shipped before a government facility is operating and fuel that does not meet the cooling requirements of the government facility (i.e., short-cooled fuel). The availability and economics of commercial AFR facilities is unknown in the 1980's and 1990's, but were considered in the study for their potential effect on the amount of fuel required to be stored in a government fuel storage facility.

The government SFHP facility in Figure 1 was assumed to utilize a dry fuel storage concept. A minimum cooling period of 5 years after reactor discharge is required prior to dry storage. Fuel is packaged and stored at 
this facility until a decision is made to either dispose or reprocess the fuel elements. Construction of this facility could expand as needed, with annual capacities of several thousand metric tons of fuel being achieved. It is expected that facilities of this type will not be available until 1985. If the water basin concept for fuel storage is adopted for government SFHP facilities, little change would be required in the parameters used to describe this facility. The minimum cooling time may be somewhat reduced but a large facility would still be required.

The government SFHP facility is to be designed for a minimum life of 25 years. When a decision is reached to either dispose or reprocess the fue 1 , rail shipments of packaged spent fuel will begin. For this study, the final fuel destination could either be at the same site as the SFHP facility or at an offsite location.

\subsubsection{Spent Fuel Transoortation Equipment}

Spent fuel is defined in 49 CFR 173 as being a type B quantity of radioactive material. This regulation requires that it be shipped in massive, impact resistant containers. Designs have been licensed in the United States for both truck and rail transport. These containers were considered in this study to be available in sufficient quantities to move fuel from nuclear power plants to commercial and government owned fuel storage facilities and from commercial to government storage facilities. No shipping containers are currently available or designed to carry packaged spent fuel. However, it was assumed for this study that existing rail casks could be modified to carry packaged fuel with reduced capacity. Spent fuel shipping containers considered in the site evaluation model are listed in Table 1.

Table 1 reports information by shipping cask model for rail, truck, and packaged fuel rail casks. Capacities are listed in fuel elements from both boiling water (BWR) and pressurized water (PWR) reactors. Round trip loading and unloading times are the sum of the time required for handling at a nuclear power facility and an away from reactor fuel storage facility. Costs reported in Table 1 are for one round trip based on one-way mileage and include cask use and transportation charges. For example, an $800 \mathrm{mile}$ round trip in an IF300 would cost $\$ 5200+400(\$ 9.70)=\$ 9080$ per metric ton of spent PWR fuel. 
TABLE 1. Spent Fuel Shipping Casks

\begin{tabular}{|c|c|c|c|c|c|c|c|c|}
\hline \multirow[b]{3}{*}{ Cask Model } & \multirow[b]{3}{*}{ Manufacturer } & \multirow{2}{*}{\multicolumn{2}{|c|}{$\frac{\text { Capacity }}{\text { (Fuel Assemblies) }}$}} & \multirow{3}{*}{$\begin{array}{c}\text { Round Trip } \\
\text { Load/Unload } \\
\begin{array}{c}\text { Time } \\
\text { (Days) }\end{array}\end{array}$} & \multicolumn{4}{|c|}{ Costs } \\
\hline & & & & & \multirow{2}{*}{\multicolumn{2}{|c|}{$\begin{array}{c}\text { Fixed } \\
\text { (\$/MT) } \\
\text { PWR }\end{array}$}} & \multicolumn{2}{|c|}{$\begin{array}{c}\text { Mileage } \\
\text { (\$/MT-mile) }\end{array}$} \\
\hline & & $\underline{\mathrm{PWR}}$ & & & & BWR & & BWR \\
\hline \multicolumn{9}{|l|}{ Rail Casks } \\
\hline IF 300 & General & & & & & & & \\
\hline & Electric & 7 & 18 & 6.7 & 5200 & 4900 & 9.70 & 9.10 \\
\hline NLI $10 / 24$ & $\begin{array}{l}\text { National Lead } \\
\text { Industries }\end{array}$ & 10 & 24 & 7.0 & 4200 & 4200 & 7.60 & 7.60 \\
\hline \multicolumn{9}{|l|}{ Truck Casks } \\
\hline NLI $1 / 2$ & $\begin{array}{l}\text { National Lead } \\
\text { Industries }\end{array}$ & 1 & 2 & 4.0 & 5370 & 6500 & 5.90 & 7.10 \\
\hline TN $8 / 9$ & $\begin{array}{l}\text { Transnuclear } \\
\text { Corp. }\end{array}$ & 3 & 7 & 4.0 & 2100 & 2200 & 2.30 & 2.40 \\
\hline NFS-4 & $\begin{array}{l}\text { Nuclear Fuel } \\
\text { Services Corp. }\end{array}$ & 1 & 2 & 3.7 & 3400 & 4100 & 4.60 & 5.50 \\
\hline \multicolumn{9}{|l|}{$\begin{array}{l}\text { Packaged Fuel } \\
\text { Casks* }\end{array}$} \\
\hline IF 300 & $N / A$ & 4 & 6 & 6.7 & 8970 & 14500 & 17.00 & 28.00 \\
\hline NLI $10 / 24$ & $N / A$ & 7 & 9 & 7.0 & 6000 & 11200 & 11.00 & 21.00 \\
\hline
\end{tabular}

* Not currently available. 
Fixed costs per round trip are the summation of cask use charges times the number of load/unload days and a minimum transportation charge. Mileage costs are the summation of per mile transportation tariffs and the daily cask use charge divided by miles traveled per day. Trucks were assumed to move 400 miles per day and trains were assumed to move 250 miles per day for this calculation. An additional charge of $\$ 19$ per one-way mile could be added to rail shipment costs if special train service charges are to be estimated. Cask use charges were developed by assuming a 12 year cask iife with 350 operating days per year for truck casks and 335 days for rail casks. A $10 \%$ interest rate was used to calculate amortized capital costs.

Transportation charges for trucks were obtained from the 1976 Tristate Motor Carrier Tariffs (Item No. 4500A). This information was modeled by the equation:

$$
\$ / \text { cask round trip }=\$ 370+\$ 1.17 / \text { one-way mile }
$$

Rail charges were estimated from Reference 2 to be:

$\$ /$ cask round trip $=\$ 5500+\$ 12.70 /$ one-way mile

With cost and performance information available for a variety of shipping containers, studies can be done to determine cask requirements for assumed variations in future cask fleets. New conceptual designs for shipping casks could also be included to measure their performance relative to existing casks.

\subsection{LOGISTICS MODELING}

A spent fuel storage Site Evaluation Model (SEM) has been developed based on the system description in Section 3.1 to aid in the evaluation of alternate locations for one or more SFHF's. This section describes the basis, structure and operation of the SEM.

\subsubsection{Model Description}

This section describes the assumptions made to obtain a model of the system described in Section 3.1. The methodology used to formulate, solve, and report results for user specified shipping strategies is also discussed. 


\section{Methodo Togy}

The SEM is an optimizing model so that transportation and storage costs are minimized for a fuel management system defined by the user. The optimization is used as a simulation technique assuming that operators of nuclear power and spent fuel storage facilities will attempt to operate at the least cost. Thus, the user designs a spent fuel handling system and allows the model determine the most cost effective operating decisions (i.e., where, when, and how nuclear power plants will ship discharged fuel). By comparing solutions to various system configurations, the user can determine trade offs from the number and varying locations of SFHF's.

The solution methodology is a highly efficient "Primal Network Algorithm," developed at the University of Texas. (3) This methodology solves a special class of linear programming problems. This methodology was selected over the conventional linear programming methods because of its extreme efficiency. Furthermore, this technique can be applied using a minicomputer. Work performed at PNL utilized a time sharing PDP 11/70. The 11/70 computer is linked with another minicomputer which includes a sophisticated interactive graphics system using light pen and geographic coding techniques. An experienced user can typically define a problem and obtain the printed results in about 20 minutes. Actual computing time is a few minutes. A user's manual for the SEM is included as Appendix $A$ of this report.

\section{Model Formulation}

The Spent Fuel Logistics Model is a balanced network model. The macro flow network is shown in Figure 2. Major activities modeled from the spent fuel shipping system are:

1. Spent fuel discharged and stored at reactor

2. Spent fuel shipping

3. Water storage away from reactors (AFR)

4. Spent fuel handling (SFHF) and disposa?.

Each activity (production, storage, shipment) in the spent fuel management system is represented by an arc in the network model. The flow value determined for the arc represents the amount of spent fuel shipped or stored 


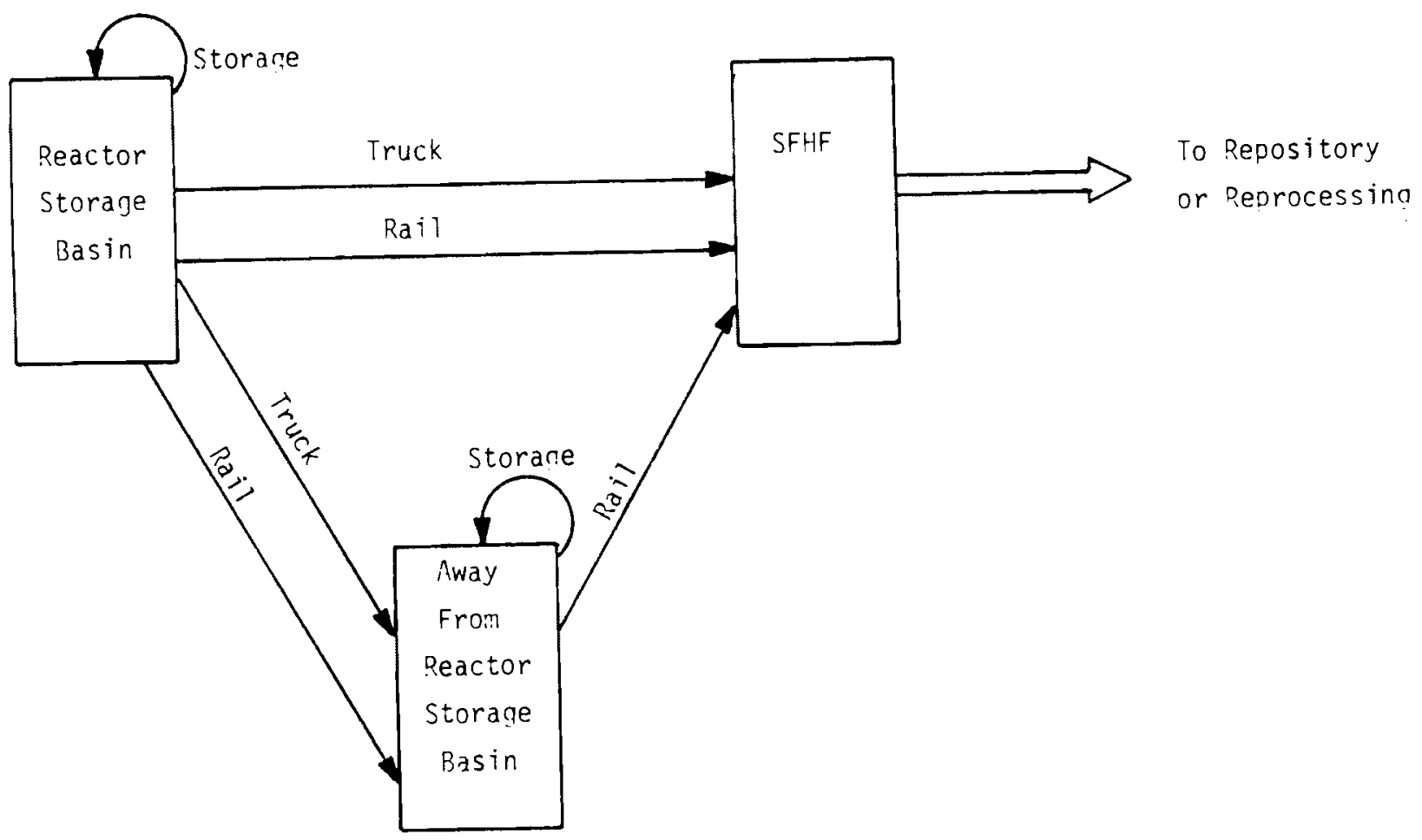

FIGURE 2. Spent Fuel Management Alternatives

during a time interval. Each arc is connected to two nodes. The flow must be balanced at each node, i.e., flow into the node equals flow out of the node. A generic node is depicted in Figure 3, where the arcs are represented by arrows. A separate shipping arc is generated for shipments by different transportation nodes and to different facilities.

Each arc has an associated cost per unit flow. Each arc also may have an upper bound and/or a lower bound. The optimization algorithm then determines the flow through all arcs such that the minimum total system cost. within the flow bounds on each arc is achieved. The upper bounds reflect physical capacity constraints on storage, shipping, and receiving facilities. Lower bounds are used on storage arcs to impose a minimum cooling time before spent fuet may be shipped. If a flow is fixed, such as reactor discharge, the upper bound is equal to the lower bound. 
Arc 1. Spent fuel discharged

Arc 2. Spent fuel stored from previous period

Arc 3. Spent fuel received from another facility

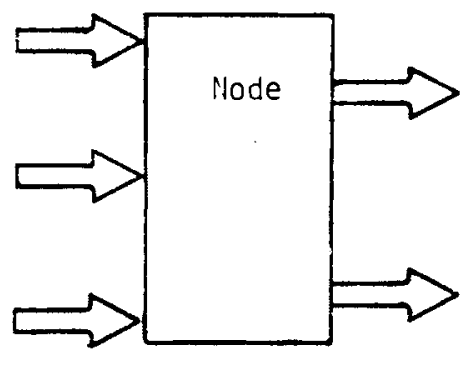

Arc 4. Spent fuel stored until next period

Arc 5. Spent fuel shipped to another facility

FIGURE 3. Diagram of a Typical Node

\section{Formulation Options and Input}

The spent fuel logistics model has been developed to provide maximum flexibility to the user in analyzing spent fuel transportation scenarios. Inputs to the model include location and startup dates for spent fuel handiing facilities and AFR's, receiving and storage capacities for these facilities, and the type of shipping casks used. The model can analyze problems with multiple SFHF and AFR's.

Specific information on existing and planned reactors is furnished to the model from a reactor data base. This data base contains the following information for each reactor:

- plant name, type (PWR or BWR) and location

- plant capacity (MWe) and startup date

- fuel storage pool capacity

- amount of fuel per reload

- length of reload cycle

Reactors may be grouped by type (BWR or PWR) and by geographic location or ownership. This grouping may be used to represent inter-reactor or intrautility shipping or may be used for calculational efficiency.

Input data is supplied by the user through an interactive computer graphics terminal. The user is presented a series of questions that he answers to define the problem under consideration. The information presented to the user includes a map of the United States showing the location of all 
light-water reactors currently operating, under construction, or planned in the U.S. through 1990. The user can enter the locations of the AFR, spent fuel handling or storage facilities and repository to be considered in the problem on this map using a light pen or the latitude and longitude of the facilities may be specified directly. Other information required of the user to define the problem being analyzed includes:

- the time period under consideration and length of time interval

- for each spent fuel handling/storage facility and AFR

- name

- startup year

- total storage capacity

- initial annual receiving rate for truck and rail shipments

- capacity expansion (if any) by year and percent

- unit transportation costs for truck and rail shipments. This is in two components, a fixed cost and a cost per mile.

- inventory costs for spent fuel storage

- cost inflation rate

- transport casks used (a mixture of casks may be specified - e.g., $80 \%$ NLI 10/24, $20 \%$ IF 300 for rail shipments)

Default values are available for most of these parameters. The user may also specify reracking of the fuel storage basins of all currently operating reactors to increase the storage capacity to a multiple of full cores. An additional option is whether or not reactor operators maintain a full-core storage reserve.

Output

Printed copies of reports and graphs can be obtained, or the results can be displayed on the video terminal. Reports currently available from the model are listed. Sample output from the model is included in Appendix $B$. other reports could be obtained with minor modifications to the report 
generator program. Virtually any information that could be obtained by analysis or manipulation of the shipping schedule could be generated. Current reports available include:

- Spent Fuel Shipment Summary Report. This report gives the amount of spent fuel shipped by truck and rail and the shipping costs for each year of the time period under consideration in the problem.

- Spent Fuel Handling/Storage Facility Summary Report. For each facility considered in the analysis this report lists the annual truck and rail receiving capacity, the amount of fuel received, the amount of fuel in storage, and the receiving capacity utilization factor for each year of the time period under investigation in the problem.

- BWR Summary Report. This report gives the total amount of fuel in BWR storage basins in the U.S., the total storage capacity of the basins, and the annual holding cost for this fuel for each year of the time period under investigation.

- PWR Summary Report. This report gives, for PWR's, the same information described above in the BWR Summary Report.

- Spent Fuel Handling/Storage Facility Cost Report. For each spent fuel handling/storage facility this report provides a summary of the amount of fuel placed in storage and the one-time handling charges collected for each year during the time period under investigation.

- Cask Utilization Report. This report presents the number of truck and rail casks required and the number of shipments made for each year of the time period under investigation.

- Report of Shipments to the Geologic Repository. For each spent fuel handling/storage facility considered in the analysis, this report lists the amount of PWR and BWR fuel shipped to the geologic repository and the shipping costs for each year of the time period under investigation.

- Cask Requirements for Shipment to Repository. This report provides the number of casks required and the number of shipments made to the geologic repository for each year of the analysis. 
- AFR Summary Report. This report presents the amount of fuel received at the commercial AFR spent fuel storage facility, the amount of fuel in storage at the facility and the amount of fuel shipped by truck and rail to the government handling/storage facility for each year of the analysis.

- Reactor Group Reports. For any selected group of reactors (or individual reactor) this report gives the amount of fuel discharged, the amount of fuel in storage, the storage basin capacity, and the amount of fuel shipped by truck and rail to the AFR and each handling/storage facility for each year of the analysis.

\subsubsection{Computer System Structure and Operation}

A diagram of the overall structure and operation of the Site Evaluation Model (SEM) is presented in Figure 4. The model is operated in several stages on two minicomputer systems linked by a data communications network. (4) The first stage is the user input or problem specification stage, which is accomplished in an interactive environment on a single-user graphics system built around a Digital Equipment Corporation PDP-11/35, a Vector General refresh CRT display, and a Gould electrostatic printer/plotter.

The SEM input graphics software allows the user to examine and modify geographic data relative to a reference map. A.7 of the nation's light-water nuclear power plants planned to be in operation by 1990 are displayed on the map by reactor type (BWR, PWR). The locations, startup dates, basin capacities, spent fuel discharge schedules, and other pertinent information on each reactor are located in a reactor data file. With the light pen, the user can isolate a specific area of the map, request an expanded detailed view of that region, and obtain a printout of information on that region. The user can also add and delete spent fuel facilities and AFR's via the map and light pen. Other user options include input and retrieval of information by coordinate reference (latitude and longitude), hardcopy output of the current map display, and the capability to place reactors which are within a specified geographic region into groups. The basis for reactor grouping can be geographic proximity, operating utility, or a combination of the two. 


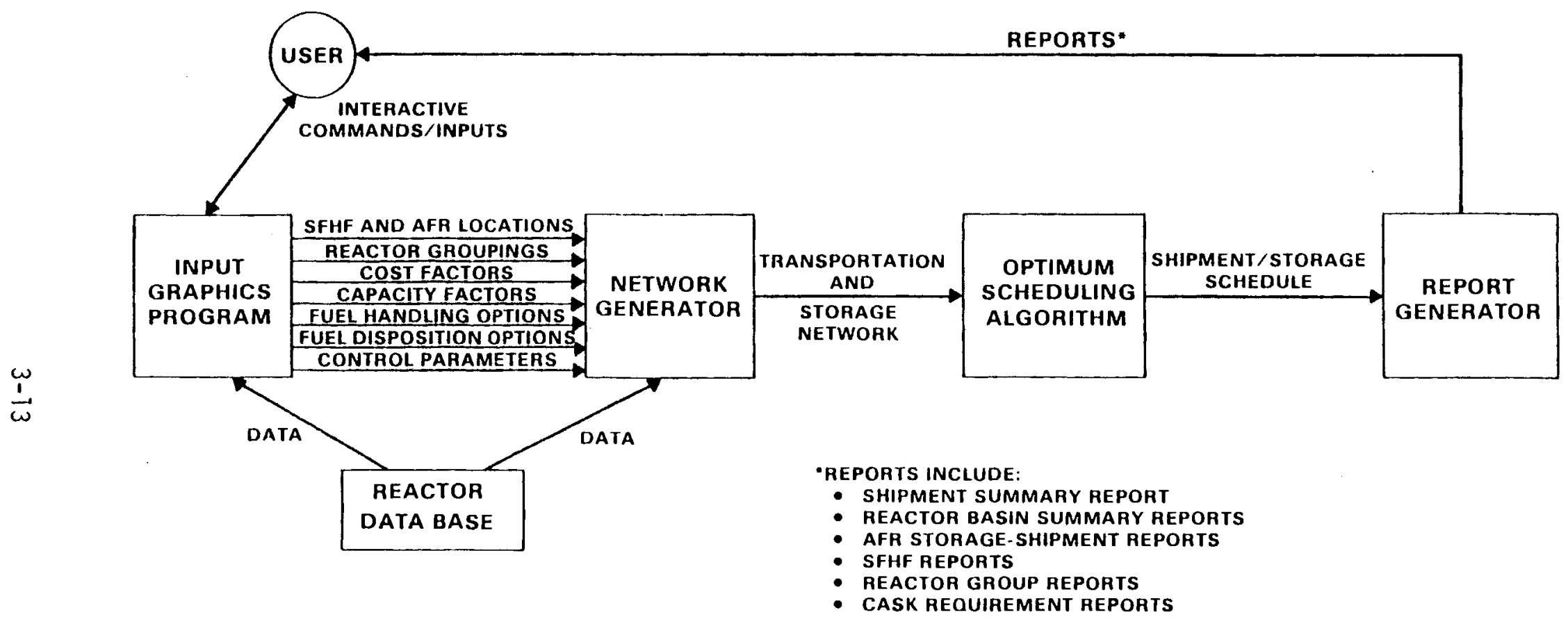

FIGURE 4. Site Evaluation Mode1--Overall Structure and Operational Flow 
When the user is satisfied with the geographic configuration of reactor groups, AFR's, and spent fuel facilities, the opportunity is provided to enter numerical values for input parameters such as per-unit cost factors, facility capacities, and startup dates, and to select from among several shipping cask design alternatives and fuel management options. The user may choose to accept default (base case) parameter values, either on an individual parameter basis or in blocks of related parameters, if he does not wish to enter all of the requested values.

When the user has completed the model input stage, the geographic, numeric, and other input values are combined into an interim data file in an alphanumeric form which is both machine-readable and human-readable (see page B-1). The input file is then transmitted via a high-speed data link to a PDP-11/70 computer, which is much more suited to the actual model computations than the graphics-oriented $11 / 35$.

It should be noted at this point that if a simulation case is to be run which differs from a previous run in only one or two parameters, then the input file from the previous case can be modified by the user on the $11 / 70$ in lieu of repeating the entire graphical input procedure.

The next stage of the SEM is the network generator. This is a computer program which converts the raw input parameters from the interim data file and the reactor data file into the network formulation required by the optimization code. The network optimization code then produces the minimum-cost shipment and storage schedule.

The output of the optimization algorithm is in an encoded form similar to the encoded network specification provided to it by the network generator. It is therefore the task of the report generator to decode this information, summarize it, and generate reports of the model results in a readable, meaningful format. Total yearly shipments by rail and by truck are tabulated in a shipment summary report. The yearly aggregate status of reactor storage basins by reactor type (BWR, PWR) is summarized in terms of the amount of spent fuel stored relative to the total capacity available. Other summary reports include the amount of spent fuel received each year at each spent fuel 
handling facility (SFHF) and each AFR. If desired, individual storage and shipment reports can be obtained for user-selected reactor groups, showing the year, amount, and destination of all shipments and the yearly basin capacity utilization.

\subsection{RESULTS}

Two analyses have been performed using the site evaluation spent fuel logistics model to determine the relative transportation system requirements and costs for alternative SFHP facility sites and alternative spent fuel disposal facility sites relative to a SFHP facility sited in the midwest, southeast or pacific northwest regions. Emphasis was placed on providing a relative comparison rather than absolute value significance of results. In particular, the mix between truck and rail shipments should be viewed as approximate.

In the first case the transportation impact of siting a single SFHP facility at one of six Department of Energy laboratory sites; Savannah River, Oak Ridge, Argonne, Idaho Fal1s, Hanford, or Nevada was examined. In this analysis, storage costs at the reactor were ignored and it was assumed that SFHP facility capacity is virtually unlimited. Thus spent fuel was shipped only as the reactor basins were filled.

Annual shipping cask requirements, annual transportation costs, and annual shipping requirements in MT-miles are presented for the six cases in Tables 2 - 4. Table 5 presents the SFHP facility requirements. The total requirements for the six cases are shown in Table 6 . This analys is shows that Argonne, Oak Ridge, and Savannah River are nearly equivalent sites for a single SFHP facility in terms of transportation requirements. Idaho Falls, Hanford, and Nevada are also nearly equivalent but require twice the number of shipping casks and total cash flows compared to the eastern sites.

The second case ${ }^{(5)}$ postulates a single SFHP facility located in the midwest, pacific northwest or the southeast. The transportation costs reported in Table 7 are a summation of reactor to storage and storage to repository 
TABLE 2. Annual Shipping Cask Requirements - Shipping Spent Fuel to Various AFR Locations

\begin{tabular}{|c|c|c|c|c|c|c|c|c|c|c|c|c|}
\hline & \multicolumn{2}{|c|}{ Argonne } & \multicolumn{2}{|c|}{ Idaho Falls } & \multicolumn{2}{|c|}{ Hanford } & \multicolumn{2}{|c|}{ Oak Ridge } & \multirow{2}{*}{$\frac{\text { Savannah }}{\text { Rail }}$} & \multirow{2}{*}{$\frac{\text { River }}{\text { Truck }}$} & \multicolumn{2}{|c|}{ Nevada } \\
\hline & Rail & Truck & Rait & Truck & Rail & Iruck & Rail & Truck & & & Rail & Truck \\
\hline 1983 & 6 & 46 & 11 & 74 & 14 & 82 & 6 & 49 & 7 & 43 & 12 & 81 \\
\hline 1984 & 4 & 15 & 7 & 27 & 8 & 30 & 4 & 15 & 4 & 17 & 7 & 30 \\
\hline 1985 & 8 & 22 & 10 & 41 & 11 & 46 & 5 & 28 & 5 & 27 & 10 & 46 \\
\hline 1986 & 7 & 43 & 11 & 69 & 13 & 78 & 6 & 36 & 7 & 47 & 12 & 76 \\
\hline 1987 & 6 & 48 & 12 & 81 & 14 & 91 & 8 & 44 & 7 & 46 & 13 & 89 \\
\hline 1988 & 9 & 49 & 17 & 97 & 19 & 125 & 8 & 56 & 8 & 60 & 1.8 & 107 \\
\hline 1989 & 12 & 68 & 23 & 123 & 26 & 137 & 11 & 67 & 12 & 70 & 24 & 135 \\
\hline 1990 & 13 & 81 & 23 & 143 & 29 & 161 & 12 & 80 & 13 & 84 & 25 & 157 \\
\hline
\end{tabular}

TABLE 3. Annual Shipping Cost for Shipping Spent Fuel to Various AFR Locations Including Cask Costs (\$Million/year)

Argonne Falls Hanford $\underline{\begin{array}{c}\text { Idaho } \\ \text { Ridge }\end{array} \text { River }}$ evada

$\begin{array}{rrrrrrr}1983 & 13 & 22 & 25 & 14 & 15 & 24 \\ 1984 & 6 & 9 & 11 & 6 & 7 & 10 \\ 1985 & 9 & 15 & 17 & 9 & 10 & 16 \\ 1986 & 14 & 22 & 25 & 13 & 14 & 23 \\ 1987 & 16 & 25 & 28 & 15 & 16 & 26 \\ 1988 & 20 & 32 & 36 & 20 & 21 & 33 \\ 1989 & 26 & 40 & 46 & 25 & 27 & 43 \\ 1990 & \frac{30}{134} & \frac{44}{209} & \frac{51}{239} & \frac{29}{131} & \frac{32}{142} & \frac{47}{224}\end{array}$


TABLE 4. Annual Spent Fuel Shipping to Various AFR Locations (million MT-miles)

\begin{tabular}{|c|c|c|c|c|c|c|c|c|c|c|c|c|}
\hline & \multicolumn{2}{|c|}{ Argonne } & \multicolumn{2}{|c|}{ Idaho Falls } & \multicolumn{2}{|c|}{ Hanford } & \multicolumn{2}{|c|}{ Oak Ridge } & \multicolumn{2}{|c|}{ Savannah River } & \multicolumn{2}{|c|}{ Nevada } \\
\hline & BWR & PWR & BWR & PWR & BWR & PWR & $\overline{B W R}$ & & & & $\underline{B W R}$ & PWR \\
\hline 1983 & 0.3 & 0.6 & 0.9 & 1.8 & 1.1 & 2.2 & 0.5 & 0.6 & 0.6 & 0.7 & 1.0 & 2.1 \\
\hline 1984 & 0.2 & 0.3 & 0.5 & 0.6 & 0.6 & 0.7 & 0.2 & 0.3 & 0.2 & 0.4 & 0.6 & 0.7 \\
\hline 1985 & 0.3 & 0.5 & 0.8 & 1.0 & 1.0 & 1.2 & 0.3 & 0.5 & 0.3 & 0.5 & 0.9 & 1.1 \\
\hline 1986 & 0.3 & 0.9 & 1.0 & 1.7 & 1.2 & 2.1 & 0.3 & 0.7 & 0.4 & 0.9 & 1.1 & 1.8 \\
\hline 1987 & 0.3 & 1.0 & 1.0 & 2.0 & 1.2 & 2.5 & 0.4 & 0.8 & 0.4 & 0.9 & 1.2 & 2.2 \\
\hline 1988 & 0.5 & 1.1 & 1.4 & 2.5 & 1.7 & 3.0 & 0.5 & 1.0 & 0.6 & 1.1 & 1.6 & 2.6 \\
\hline 1989 & 0.7 & 1.5 & 2.2 & 3.0 & 2.4 & 3.6 & 0.6 & 1.4 & 0.8 & 1.6 & 2.2 & 3.3 \\
\hline 1990 & 0.7 & 1.8 & 1.9 & 3.5 & 2.6 & 4.2 & 0.7 & 1.8 & 0.9 & 2.0 & 2.3 & 3.8 \\
\hline TOTAL & 3.2 & 7.7 & 9.6 & 16.1 & 11.9 & 19.6 & 3.4 & 7.1 & 4.2 & 8.0 & 11.0 & 17.5 \\
\hline
\end{tabular}

TABLE 5. Annual Spent Fuel Shipment to AFR (MT)

\begin{tabular}{|c|c|c|}
\hline & $\frac{\text { Al1 A }}{\text { BWR }}$ & $\frac{i \text { tes }}{\text { PWR }}$ \\
\hline 1983 & 696 & 1,296 \\
\hline 1984 & 416 & 436 \\
\hline 1985 & 824 & 660 \\
\hline 1986 & 660 & 1,360 \\
\hline 1987 & 552 & 1,444 \\
\hline 1988 & 912 & 1,472 \\
\hline 1989 & 1,204 & 2,008 \\
\hline 1990 & 1,360 & 2,428 \\
\hline TOTAL & 6,624 & 11,104 \\
\hline
\end{tabular}


TABLE 6. Summary of Spent Fuel Shipped to Various AFR Locations - 1983 through 1990

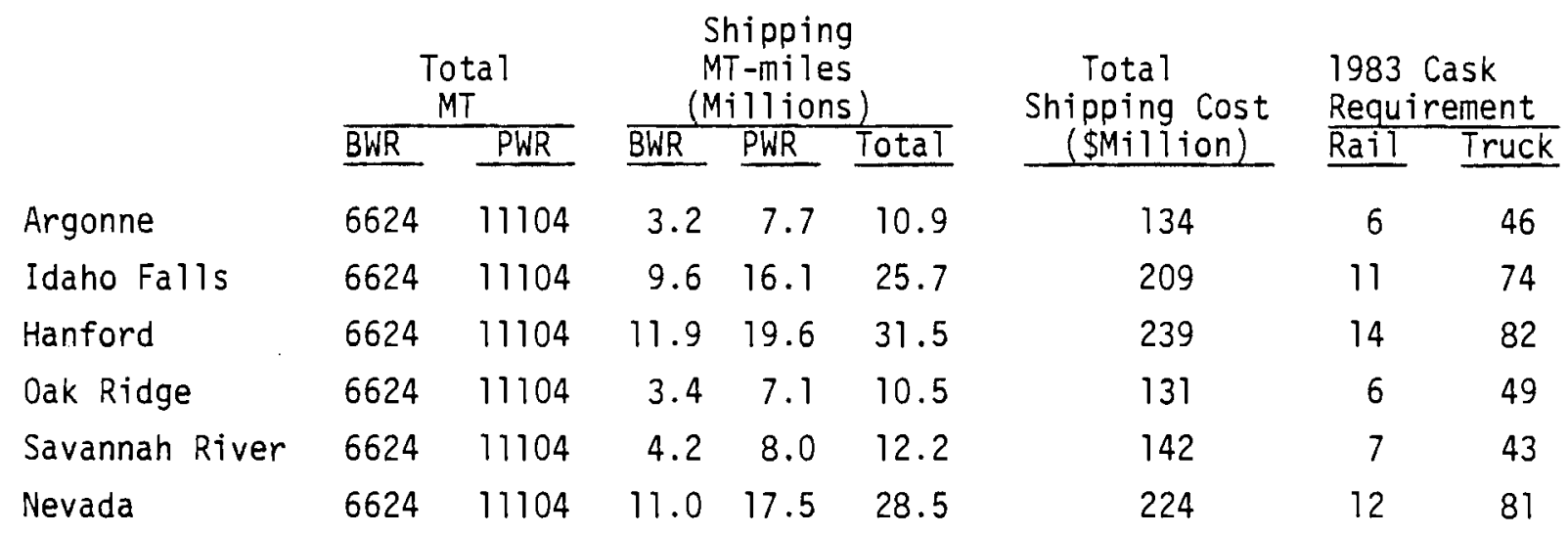

TABLE 7. Transportation Costs for Options in Spent Fuel Storage Facility and Spent Fuel Repository Sites

Facility Location Transportation Costs $\left(\$ 10^{6}\right)$

\begin{tabular}{|c|c|c|c|c|}
\hline Storage & Site $(s)$ & Waste Repository & To Storage & Total \\
\hline & $\operatorname{MWR}^{(a)}$ & SE & 385 & 800 \\
\hline 2 & $\operatorname{MWR}{ }^{(a)}$ & PNW(b) & 385 & 1130 \\
\hline 3 & $\operatorname{MWR}(a)$ & SW & 385 & 1101 \\
\hline 4 & $\mathrm{PNW}^{(b)}$ & SW & 802 & 1220 \\
\hline 5 & SE & SW & 413 & 1280 \\
\hline
\end{tabular}

(a) Midwest Region

(b) Pacific Northwest 
costs in constant dollars for the years 1985 to 1995 . The amount of fuel predicted to move during this period is 41,000 MT. Ninety percent of the fuel was assumed to move by rail and ten percent by truck. Colocation of a SFHP facility and a spent fuel repository would make the total costs equal to the "to storage" costs. The results show that a colocation strategy in the east would be the lowest cost option. A somewhat higher cost strategy would have storage and repository facilities located in the east (Case 1). Strategies which involve locating a SFHP facility and a spent fuel repository at opposite sides of the country (Cases $2,3,5$ ) or both facilities in the west (Case 4) can be seen to have the highest total costs. Short-term (to storage) costs are maximized for a SFHP facility located in the west.

\section{REFERENCES}

1. C. H. Woodha 11, U.S. LWR Spent Fuel Inventory and Projection, 4/OWI/SUB-77/42500, Nuclear Assurance Corporation, June 1977.

2. R. E. Rhoads, et al, A Safety and Economic Study of Special Trains for Shipment of Spent Fuel, BNWL-2263, Pacific Northwest Laboratory, Richland, Washington 99352, December 1977.

3. CCS 257, "Solving Constrained Generalized Network Problems," John Hultz and D. Klingman, Center for Cybernetic Studies, University of Texas, November 1976.

4. L. Gerhardstein, J. Schroeder, and A. Boland, "The Pacific Northwest Laboratory Minicomputer Network," Presented at Third Berkeley Workshop on Distributed Data Management and Computer Networks, Berkeley, California, Third Berkeley Workshop Proceedings, August 1978.

5. W. B. Andrews, R. A. Burnett, R. L. Engel, Transportation Logistics for Spent Fuel Storage and Disposal, PNL-SA-7030S. ANS Transactions, vol. 30, November 1978. 



\subsection{PACIFIC NORTHWEST LABORATORY FACILITY \\ SIMULATION MODEL}

The facility simulation model was developed to provide quantitative logistics information as an aid in the design of a Spent Fuel Storage and/or Handling and Packaging Facility. The model can be useful in optimizing the design and operation of the spent fuel handling/storage facility; in analyzing the effects of changes in the transportation system on the efficiency of operating the spent fuel handling/storage facility; and in analyzing the effects of facility design changes on the transportation system.

The model uses a general methodology that can be used for evaluating the performance of any previously defined system. If the input parameters are realistically defined, then it will be possible to infer behavior of the system from observations of behavior of the model. The flexibility of the model permits alteration of system parameters to study the impact of these changes on the operation of the system. In this way, a series of "what if?" questions may be used to gain understanding about the operation of the system.

The first task in conducting a simulation of the spent fuel handling facility was to develop a realistic representation of the system for analysis. This model should incorporate varying amounts of detail depending on the goal of the analysis. For example, a designer of a specific piece of equipment may require many details for one spent fuel handling operation, but others could be represented by a "black box" approach. Major elements of the spent fuel receiving facility used in the sample analysis case are shown in Figure 5. A facility capable of handling 3000 MT of fuel per year is represented. The goal of this case was to simulate overall facility performance, so that equipment requirements could be determined. Operating requirements include:

- A receiving and surge storage system compatible with spent fuel acceptance criteria, shipping cask configuration criteria, and transport practices,

- An encapsulation rate which will result in a facility of reasonable economic size compatible with overall program requirements, 


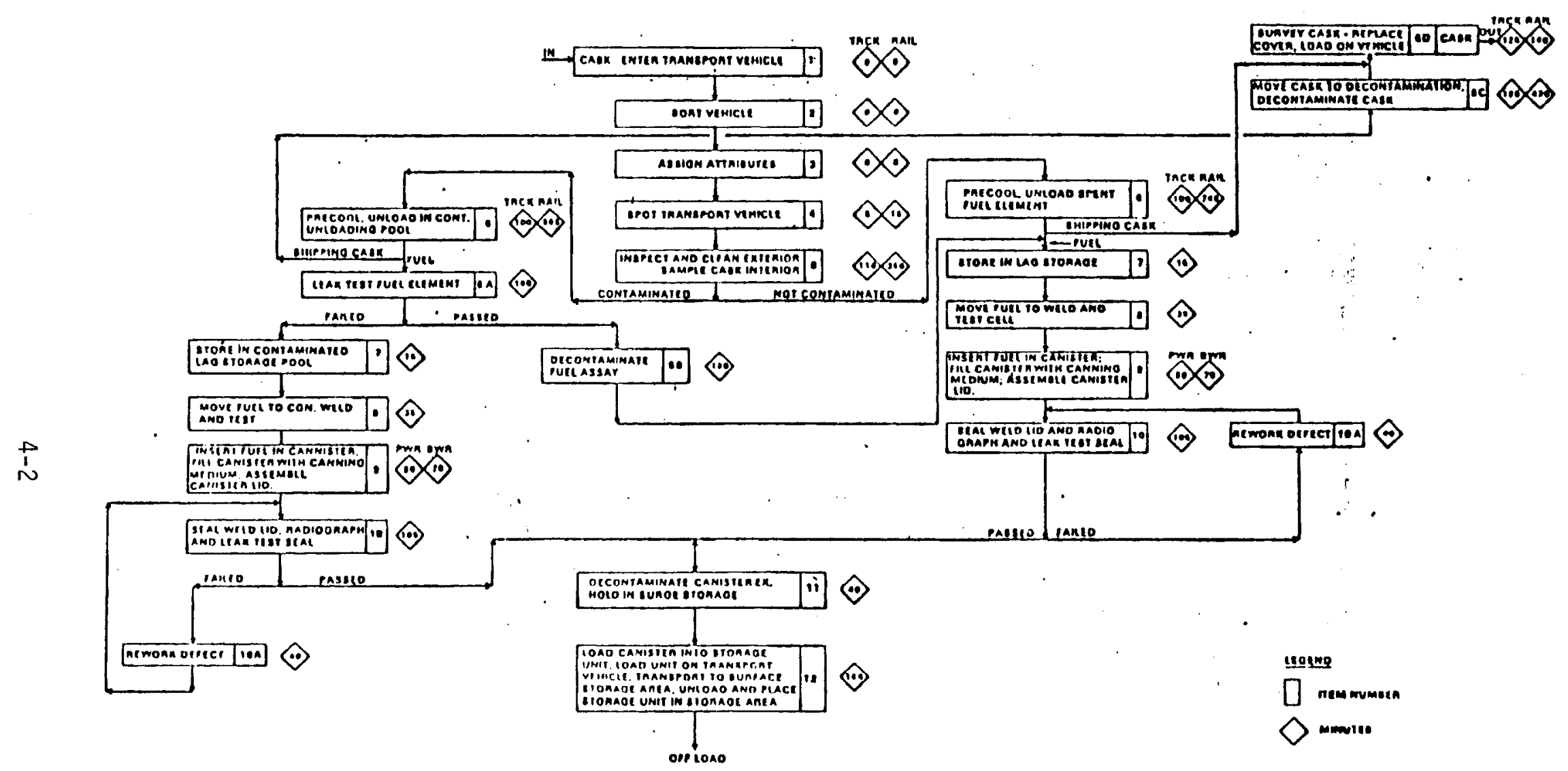

FIGURE 5. Sample Case Process Diagram 
- Isolation and confinement of radioactive materials to meet all Federal, State and local regulations,

- Flexibility and reliability to handle damaged fuel or partial assemblies,

- Strict accountability of spent fuel inventory,

- Security, monitoring, and surveillance.

Specific information needed to define system operation such as spent fuel assembly arrival rates, type of fuel (PWR or BWR), and method of arrival (truck or railroad) can be furnished by the site evaluation model or direct user input. Values used in the sample case are listed in Table 8 . While these values may not be realistic, they do illustrate the data requirements for a problem of this type. Additional information and alternative design values can be considered. The type of input information required depends on the desired results. For example, as an alternative conceptual design methodology the entire spent fuel handling system may be specified. The same facility model could then be used to determine the facility throughput.

Simulation analysis is accomplished with the use of the Q-GERT software package. (1) This is a method for graphically modeling systems in a manner that permits direct computer analysis. Analysis of a Q-GERT network is adaptable to a wide class of computers. The analysis program employs discreet event procedures to analyze the flow of transactions through the network in order to obtain statistical estimates of the quantities prescribed on the network model. The performance of activities associated with the network are simulated by selecting a time for the activity in accordance with the distribution type and parameter values prescribed for the activity. When the simulation if completed, based on user inputed conditions, summary statistics are collected and outputed for analysis.

Results of the sample conceptual design problem to specify equipment capacities are presented in Table 9 . The next step in an actual design problem would be to postulate and simulate alternative assumptions for each process step to determine system sersitivity to these parameters. In this way critical paths can be identified along with a distribution for facility 
TABLE 8. SPECIFICATIONS AND ASSUMPTIONS

I. OPERATION
A. Through Put
1. $10 \mathrm{Mt} / \mathrm{day}$
2. $24 \mathrm{hr} /$ day operation
3. 300 day/year availability
B. Working Inventory
1. 300 Mt minimum

II. CASK DESCRIPTION
A. Rail Cask
1. 7 PWR or 18 BWR assemblies
B. Truck Cask
1. 1 PWR or 2 BWR assemblies

III. FUEL DESCRIPTION
A. PWR
1. .46 MT/assembly
B. BWR
1. .19 MT/assembly
C. Mixture
1. $60 \%$ received tota $1=B W R$
2. $40 \%$ received total $=P W R$
3. $70 \%$ Rail
4. $30 \%$ Truck
D. Quality
1. $20 \%$ received in failed fuel containers
2. $10 \%$ failed during shipping, handiing, or storage

IV. OFFLOAD

A. Two Transport Vehicles (20 offloads/day)

B. Offload Storage Canister

1. 1 PWR

2. 3 BWR

V. DESIGN LIFE CYCLE (FACILITY AND EQUIPMENT) - 40 YEARS 
TABLE 9. EXAMPLE OF SAMPLE RESULTS

\section{MINIMUM RECEIVING SITE CAPACITY}

A. Non-Parallels Process Sites

1. Receiving/Shipping - 5R (Rai7)/8T (Truck)

2. Holding $-9 R / 32 T$

3. Maintenance $\quad-1 R / 1 T$

B. Parallels Process Sites (1 Cask/Site)

1. Preparation Area " 4

2. Cask Loading/Offloading 4

3. Cask Decontamination 3

4. Cask Cooling \& Washdown 2

5. Fuel Unloading Pool 3

C. Storage Pool

1. Two pools

2. $400 \mathrm{MT} / \mathrm{p} 00 \mathrm{l}$

D. Presentation Pool

1. 16 MT failed fuel

2. 50 MT buffer inventory 
performance. Further analysis of the results could lead to modifications of the process. Synthesis is accomplished through the operator ingenuity using the analysis capability of the program so that facility requirements are met.

\section{REFERENCE}

1. Pritsker, A., Modeling and Analysis Using Q-GERT Networks, John Wiley and Sons, New York, 1977. 
APPENDIX A

PACIFIC NORTHWEST LABORATORY

SITE EVALUATION MODEL

USER'S GUIDE 


\section{PNL SITE EVALUATION MODEL -- USER'S GUIDE}

\section{Overview}

The computer programs which make up the PNL Spent Fuel Transportation Logistics Model (Site Evaluation Mode1) are operated in several stages on two minicomputer systems at PNL:

1) A Digital Equipment Corporation (DEC) PDP-11/35 to which is connected a Vector General graphic display unit and a Gould electrostatic hardcopy graphics printer to form an interactive computer graphics facility. This facility, known as MINERVA, is located in Room 1154 of the Math Building in the Battelle, Pacific Northwest Laboratory complex. The $11 / 35$ runs under DEC's RT-11 single-user operating system.

2) A DEC PDP-11/70, located in the Biometrics Computer Center (Room 1240) of the LSL-II Building. The $11 / 70$ operates under the IAS multiuser operating system.

These two computers are interconnected via BATNET; the Battelle minicomputer data communications network (1).

The sequence of programs which must be operated to generate a complete Site Evaluation Model run (case) is as follows (refer to Figure 4, page 3-13 of this report):

1) Input Graphics Program (PDP-11/35). This program runs on the PDP-11/35 graphics system and provides the user with the ability to graphically specify the logistics system configuration which he wishes to evaluate. Spent fuel facility site locations can be specified with reference to a displayed map of the United States upon which the locations of all reactors in the data base are shown. Numeric cost and capacity parameter values can also be entered into the model input file created by this program. 
2) Transmission of Input File to PDP-11/70 via BATNET. Since the remainder of the model programs run on the $11 / 70$, it is necessary to transmit the model input file created by the input graphics program from the PDP-11/35 to the $11 / 70$. (Note: The mode1 input file for case studies requiring only minor changes in the problem specification of a previously run case can often be created by simply editing the corresponding existing alphanumeric input file using one of the PDP-11/70's text editors, thus avoiding steps 1 and 2.)

3) Network Generator (PDP-11/70). The network generator is a code which converts the raw input parameters from the model input file and the appropriate data values from the reactor data base into an encoded transportation/storage network formulation (problem statement) of the type required by the optimal scheduling algorithm. The network generator is real7y the heart of the site evaluation model in that the spent fuel logistics network which it produces is a representation of all the inputs and assumptions on which the model is based.

4) Optima1 Scheduling Algorithm (PDP-11/70). The network optimization code PNET (2) contains a mathematical programming algorithm which produces a minimum-cost spent fuel shipment/storage schedule over the time horizon of interest. The output of the optimization algorithm is also in the form of an encoded network specification which includes the required flows (amount of spent fuel shipped or stored) along each path in the network. 
5) Report Generator (PDP-11/70). The report generator is a program which decodes the output of the optimal scheduling algorithm and produces printed reports on the yearly spent fuel shipment/storage activity predicted by the model. Reports can be requested by the user at several levels of detail, from individual reactor or spent fuel facility reports to summary reports over all reactors and/or spent fuel facilities.

The following sections provide detailed instructions for operating each of these programs. Command requests or prompts typed by the software (rather than by the user) are underlined for clarity.

Input Graphics Program

The PDP-11/35 graphics system has two Model RK05 removable cartridge disk drives. The spent fuel logistics model input graphics program operates with program and data files stored on the disk pack labeled "Logistics \#1," which must be mounted in the lower disk driver (RK1:). The "RT11-Vø2C" system pack must be mounted in the upper drive (RKØ:).

After the system has been initialized and the date and time entered (see RT-11 user manuals for this procedure), one additional system instruction is necessary to permit the interactive use of the Vector General display unit. Type on the Decwriter console keyboard:

$$
\therefore \text { SET USR NOSWAPZ }
$$

where $\mathcal{L}$ indicates the "carriage-return" key.

The spent fuel logistics model input graphics program can be invoked in one of two ways. If you type

$$
\therefore \text { RUN DDDTPZ }
$$

PLEASE ENTER TREE FILE DESCRIPTOR: RK1:LOGIST.TRE 
you will invoke a utility program which puts a sequence of messages on the display screen. These messages provide a general description of the purpose and operation of the spent fuel logistics model. Alternatively, these messages can be bypassed by typing

$\perp$ RUN RK1:SURF2D 2

Following the messages, a map of the United States similar to Figure $A-1$ with outlines of the contiguous 48 states is displayed on the graphics units. The locations of all the nuclear power plants in the reactor data base are shown on the map. Boiling water reactors (BWR's) are indicated by an asterik, and pressurized water reactors are represented by a small triangle. A list of the single keystroke commands available to the user, with a brief description of each command, is superimposed on the map. This command 1 ist disappears when the first command is received, but it can be recalled by the "H" or "?" command. (A second set of commands appears whenever cursor mode is entered. See below.)

You can now use the Vector General keyboard and light pen to position a cursor, isolate and examine in greater detail a specific area of the map, request a printout of data on al1 reactors in a given area, and specify the location of one or more spent fuel facilities to be included in the logistics system to be investigated. SFHF's are indicated by the letter $S$ on the map, while AFR's are indicated by an $X$. Other commands a17ow grouping of reactors and generation of hardcopy output. A reactor group is indicated on the map display by a letter $G$ at the centroid of a 71 reactors in the group, with lines going out to each reactor in the group.

Table A-1 lists and describes each of the graphics commands. Note that these commands are entered by typing a single key on the Vector General 


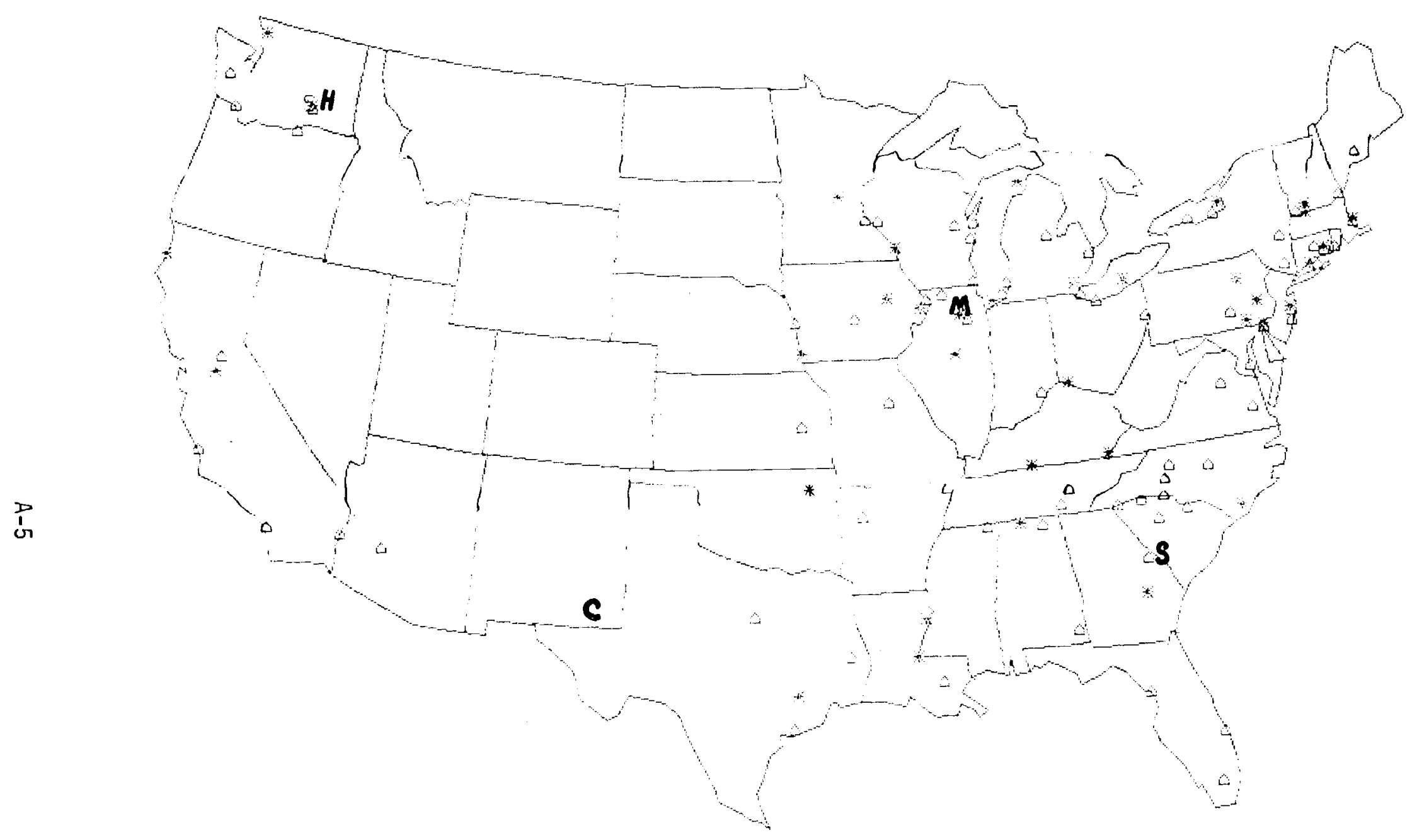

LEGEND: * EWR $\triangle$ PWR H-HANFORD S- SAYANNAH C - CARLSBAD M-MORRIS

FIGURE A-1. Site Evaluation Model Geographic Display 
keyboard, not the Decwriter console keyboard. Note also that there are two sets of commands. One set is in effect when the cursor is visible on the screen (cursor mode); the other set is in effect when the cursor is not displayed (non-cursor mode). The cursor is easily identified as an octagon of varying size, inside of which is a pius sign ("cross hairs") identifying a specific point on the map. The display window referred to in the table is an imaginary rectangle drawn around the portion of the map which is displayed (filling the screen) at a given time.

Once you have the facility configuration which you wish to investigate, you can leave the map display mode by typing "CONTROL-D." You will then be asked (by messages appearing on the screen) to enter a series of parameter values which are to be used as inputs to the Site Evaluation Model. Included are such things as cost factors, capacity factors, facility startup dates, and fuel management options. These values must be entered on the Vector General keyboard. A list of the input request messages and required user responses is given in Table A-2.

When all required parameter values have been entered, these values are combined with the facility locations and reactor grouping information to form a data file which will be input to the Site Evaluation Model. This file must now be transferred to the PDP-11/70.

\section{Input File Transmission to PDP-11/70}

The transfer of the input file from the $11 / 35$ to the $11 / 70$ is accomplished with a BATNET file transfer utility program which exists on both computers.

On the PDP-11/35, you must type the following:

- RUN XFILES 子

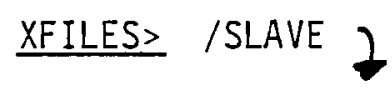


You are now ready to begin operation on the $11 / 70$. Find an available termina 1, type "CTRL-C," and enter the proper account name and password (see R. A. Burnett $(375-2313)$ or the $11 / 70$ system manager for the current account and password).

Now type:

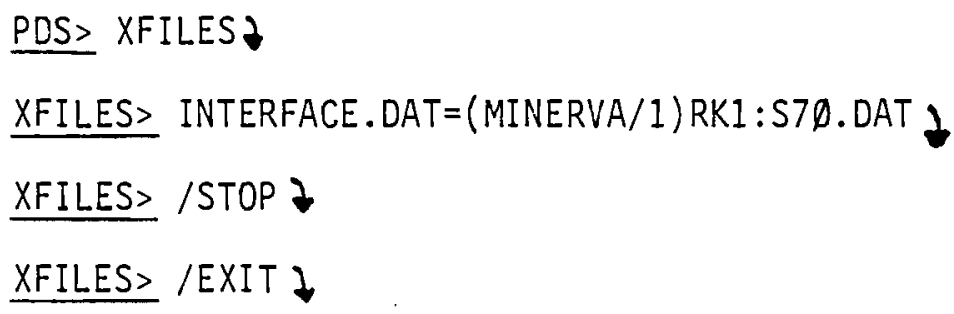

This completes the transfer of the mode? input file to the $11 / 70$. (Note: INTERFACE.DAT is the required $11 / 70$ model input file name. S7D.DAT is the name of the file created on the $11 / 35$ (MINERVA), on device RKI:.) A sample input file is listed in Appendix $B$.

\section{Editing the Model Input File}

For studies involving minor parametric variations between cases, a file previously created and transmitted to the $11 / 70$ can be edited in 1 ieu of using the graphics program to create a new input file. Any of the $11 / 70$ text editors (such as EDIT or TECO) can be used. See the appropriate $11 / 70$ software manual for instructions.

Running the Network Generator, Optimal Scheduling Algorithm, and Report Generator

The network generator (NETGEN5) and the optimal scheduling algorithm (NETMOD1C) both run without user intervention. These two programs and the report generator (NEWTEST5) can be executed sequentialiy by invoking the command file RUN5.CMD:

\section{$\underline{P D S>}$ QRUN5 7}


The network generator will produce a print file which reports statistics on the network which is generated. This printout will also contain reports of forced spent fuel shipments (to the nearest AFR) due to a reactor's storage basin capacity being exceeded prior to the availability of a SFHF (or as a result of the minimum cooling time requirement before shipping to a SFHF). Combined constraints which may render the problem infeasible are also reported (such as total storage and facility receiving capacity for a given year being less than total accumulated spent fuel discharged up to and including that year).

The number of nodes (flow sources/destination) and arcs (flow paths) are also reported on both the printout and the user's terminal. The current maximum number of nodes allowed by the Site Evaluation Model is 1350; the maximum number of arcs is 4980 . CPU times for a network of approximately this size generally average about 30 seconds for NETGEN5 and about 2 minutes for NETMODIC. Elapsed clock time for these two programs together varies from about 5 to 15 minutes, depending on the number and computational usage of other $11 / 70$ users.

After the optimization algorithm has produced the solution to the network flow problem (optimal spent fuel shipment/storage schedule), the report generator program begins execution. The report generator requires some user interaction. The following questions will be asked, with responses required as indicated:

- DO YOUR WANT COSTS REPORTED IN CONSTANT OR INFLATED DOLLARS? (ENTER C OR I) >

(If I is entered, you will be asked to enter the percent annual inflation rate.) 
- You will be shown a table of truck cask types, with a numeric code and the capacity in number of BWR or PWR fuel assemblies for each cask. You will then be asked to enter the numeric code for the truck cask type to be assumed.

- A similar option is presented for rail casks.

- DO YOU WISH TO HAVE SPENT FUEL HANDLING FACILITY STORAGE COST REPORTS PRINTED? ENTER Y (YES) OR N (NO) $>$

- DO YOU WISH TO HAVE FINAL DESTINATION SHIPMENT REPORTS PRINTED? ( $Y$ OR N)>

- DO YOU HISH TO SEE AFR STORAGE/SHIPMENT REPORTS? ENTER P (PRINT), I (TYPE ON TERMINAL), OR N (NO) >

- DO YOU WANT A COMPLETE SET OF REACTOR GROUP REPORTS? (Y OR N)>

(If you answer yes, the program will terminate when all of the reports are generated. If your answer is no, the following question will appear:)

- DO YOU WANT AN INDIVIDUAL REACTOR GROUP REPORT? (P,T, OR N)>

(If the answer is no, the program terminates. If the answer is $P$ or $T$, the next question is asked:)

- ENTER REACTOR GROUP NUMBER>

The report for that group is generated and the previous question is then repeated to see if more reactor group reports are desired.

Examples of each of the different types of printed reports which can

be produced by the report generator are given in Appendix $B$.

This concludes the running of a Site Evaluation Model. 
TABLE A-1. SEM GRAPHICS COMMANDS

$\underline{K E Y *}$

DESCRIPTION

NON-CURSOR MODE:

\begin{tabular}{|c|c|}
\hline A & Print the location of all AFR's currently on the map. \\
\hline B & Display BWR's onty. \\
\hline C & Generate a hard copy of the current display. \\
\hline G & $\begin{array}{l}\text { Group the reactors by proximity. (A message will ask the } \\
\text { user to enter the maximum separation distance for inclusion } \\
\text { in a group.) }\end{array}$ \\
\hline H or ? & $\begin{array}{l}\text { HELP (Display a list and brief description of non-cursor } \\
\text { commands.) }\end{array}$ \\
\hline I & Zoom in on the current map. \\
\hline$L$ & $\begin{array}{l}\text { Use keyboard* to enter a location (longitude, latitude) of } \\
\text { an an SFHF to be added to the map. }\end{array}$ \\
\hline$M$ & $\begin{array}{l}\text { Use keyboard* to enter a location of an AFR to be added to } \\
\text { the map. }\end{array}$ \\
\hline 0 & Zoom out. \\
\hline$P$ & Display PWR's only. \\
\hline$R$ & Display both BWR and PWR reactors. \\
\hline S & Print the location of a 11 SFHF's currently on the map. \\
\hline$T$ & Switch to cursor (tracking cross) mode. \\
\hline$U$ & Group the reactors by utility company. \\
\hline Up-arrow $(\uparrow)$ & Move the display window upward. \\
\hline Down-arrow $(\downarrow)$ & Move the display window downward. \\
\hline Left-arrow $(+)$ & Move the display window to the left. \\
\hline Right-arrow $(\rightarrow)$ & Move the display window to the right. \\
\hline $\begin{array}{l}\text { CTRL-D } \\
\text { (Control-D) }\end{array}$ & Done with map; proceed to parameter inputs. \\
\hline
\end{tabular}

*Vector General keyboard 
TABLE A-1. (cont.)

KEY

CTRL-Q

CTRL $-Z$

"HOME"

CURSOR MODE:
DESCRIPTION

Save current reactor groups in a temporary file.

Retrieve reactor groups from temporary file.

Return to original map of entire conterminous United States. $\because$

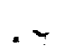
Darrow $(\uparrow)$

Down-arrow ( $t$ ) Move cursor one step downward.

Left-arrow $(*)$ Move cursor one step to the left.

Right-arrow $(\rightarrow)$ Move cursor one step to the right.

"DEL" Delete all SFHF's within octagon.

"ESC" Erase cursor, return to non-cursor mode.

"GS" Increase cursor step size.

"HOME" Return cursor location to center of screen.

"RS" Reduce cursor step size.

CTRL-R

(Control-R)

CTRL-W

(Control-W)
Print information on reactors within octagon.

Create a new display window from the current octagon position. 
TABLE A-2. USER INTERACTION SEQUENCE FOR SEMINPUT PARAMETERS

PLEASE ENTER A TITLE OR DESCRIPTION OF THIS SCENARIO:

$\geq$ (User enters titie.)

ENTER THE STARTING YEAR:

$\geq$

ENTER THE ENDING YEAR:

$\geq$

ENTER THE NUMBER OF YEARS PER TIME PERIOD:

$\geq$

ENTER THE MINIMUM NO. OF YEARS COOLING TIME FOR WATER BASIN STORAGE:

$\geq$

DO YOU WISH TO EXERCISE THE FULL CORE RESERVE OPTION? ( $Y$ OR N)

$\geq$

DO YOU WISH TO ALLOW RERACKING OF REACTOR BASINS? (Y OR N)

$\geq$

If yes:

PLEASE ENTER THE RERACKING LIMIT (NO. OF CORES): $\geq$

(Screen is erased and a new "page" of requests begins.)

SFHF NO. 1 (Name of SFHF is displayed.)

PLEASE ENTER THE TOTAL STORAGE CAPACITY FOR THIS SFHF: $\geq$

ENTER THE ONE-TIME SFHF STORAGE COST (DOLLARS PER METRIC TON HEAVY METAL): $\geq$

ENTER THE STARTUP YEAR FOR THIS SFHF:

$\geq$

ENTER THE INITIAL RECEIVING CAPACITY BY RAIL (METRIC TONS PER YEAR):

$\geq$

ENTER THE INITIAL RECEIVING CAPACITY BY TRUCK (METRIC TONS PER YEAR): $\geq$ 
TABLE A-2. (cont.)

ENTER THE INITIAL SERVICE CAPACITY (MT PER YEAR):

$\geq$

DO YOU WISH TO ENTER FURTHER CAPACITY EXPANSION DATA FOR THIS SFHF? (Y OR N)

$\geq$

(If yes, the following two requests will be issued, after which the previous question will be repeated.)

ENTER THE YEAR OF SFHF EXPANSION:

$\geq$

ENTER THE CAPACITY EXPANSION (PERCENT) FOR RAIL, TRUCK, AND SERVICE (USE COMMAS TO SEPARATE THE THREE NUMBERS):

$\geq$

(The screen is erased and the above sequence is repeated for each additional SFHF.)

AFR NO. 1 (Name of AFR is displayed.)

PLEASE ENTER THE TOTAL STORAGE CAPACITY FOR THIS AFR:

$\geq$

ENTER THE BWR FUEL STORAGE COST AT THIS AFR (DOLLARS PER MT PER YEAR):

$\geq$

ENTER THE PWR FUEL STORAGE COST (DOLLARS PER MT PER YEAR):

$\geq$

ENTER THE STARTUP YEAR FOR THIS AFR FACILITY:

$\geq$

(The screen is erased and the above sequence repeated for each additional AFR.)

DO YOU WISH TO USE THE STANDARD (BASE CASE) COST FACTORS? (Y OR N)

$\geq$

(If yes, the following requests are issued.)

PLEASE SPECIFY COST FACTORS IN DOLLARS PER METRIC TON. VARIABLE

TRANSPORTATION COSTS MUST BE IN DOLLARS PER MT PER MILE. IF AT ANY

POINT YOU WISH TO RESTART THIS SEQUENCE OF INPUTS, TYPE "R." 
TABLE A-2. (cont.)

ENTER THE FIXED PORTION OF RAIL COSTS FOR BWR FUEL:

$\geq$

ENTER THE VARIABLE PORTION OF RAIL COSTS FOR BWR FUEL:

$\geq$

ENTER THE FIXED PORTION OF TRUCK COSTS FOR BWR FUEL:

$\geq$

ENTER THE VARIABLE PORTION OF TRUCK COSTS FOR BWR FUEL:

$\geq$

ENTER THE FIXED PORTION OF RAIL COSTS FOR PWR FUEL:

$\geq$

ENTER THE VARIABLE PORTION OF RAIL COSTS FOR PUR FUEL:

$\geq$

ENTER THE FIXED PORTION OF TRUCK COSTS FOR PWR FUEL:

$\geq$

ENTER THE VARIABLE PORTION OF TRUCK COSTS FOR PWR FUEL:

$\geq$

ENTER THE BNR YEARLY HOLDING COST FACTOR (FOR ON-SITE STORAGE):

$\geq$

ENTER THE PWR YEARLY HOLDING COST FACTOR:

$\geq$

ENTER THE ANNUAL MONETARY INFLATION RATE AS A PERCENTAGE (ENTER DISCOUNT RATE AS A NEGATIVE PERCENTAGE):

$\geq$ 
1. L. Gerhardstein, J. Schroeder, and A. Boland, "The Pacific Northwest Laboratory Minicomputer Network." Third Berkeley Workshop Proceedings, Berkeley, CA, pp. 144-158, August 1978.

2. F. Glover, D. Karney, and D. Klingman, "Implementation and Computational Study on Start Procedures and Basic Change Criteria for a Primal Network Code." Networks, $4(3): 191-212,1974$. 
$\therefore$

$\sim$ 
APPENDIX B

SAMPLE SITE EVALUATION MODEL INPUT AND OUTPUT 


\section{SAMPLE SITE EVALUATION MODEL INPUT AND OUTPUT}

This appendix contains the input and output listings of a sample logistics case run on the PNL Site Evaluation Model (SEM)*. The example case includes two spent fuel handling and packaging facilities (SFHF's): the first located in the vicinity of Oak Ridge, Tennessee, scheduled to begin operation in 1983; and the second facility located in the Carlsbad, New Mexico region, scheduled to start up in 1990. The Carlsbad facility is assumed to be co-located with a geologic repository, which is to be the final destination of spent fuel shipped to both SFHF's. A commerical away-from-reactor (AFR) water basin storage facility at Morris, Illinois, is assumed to be available prior to and throughout the period of interest (1979 through 1992). Transportation and storage cost factors are chosen such that it is economically advantageous for the reactors to retain spent fuel in their on-site basins for as long as possible (until the basin capacity is exceeded by the cumulative discharge). A lower one-time storage fee at the Carlsbad SFHF relative to that at the Oak Ridge facility provides a preferential incentive to ship to Carlsbad when that facility goes on-line.

Figure $B 1$ is a listing of the VSM input file for this example case. Figures B2 through B15 contain a complete set of output reports for this case, with the exception that the two-page reactor group report is presented for only one reactor group (Group 40, Figures B14 and B15).

\footnotetext{
*The facility locations and starting dates used in the example case were selected solely on the basis of demonstrating the capabilities of the model.
} 


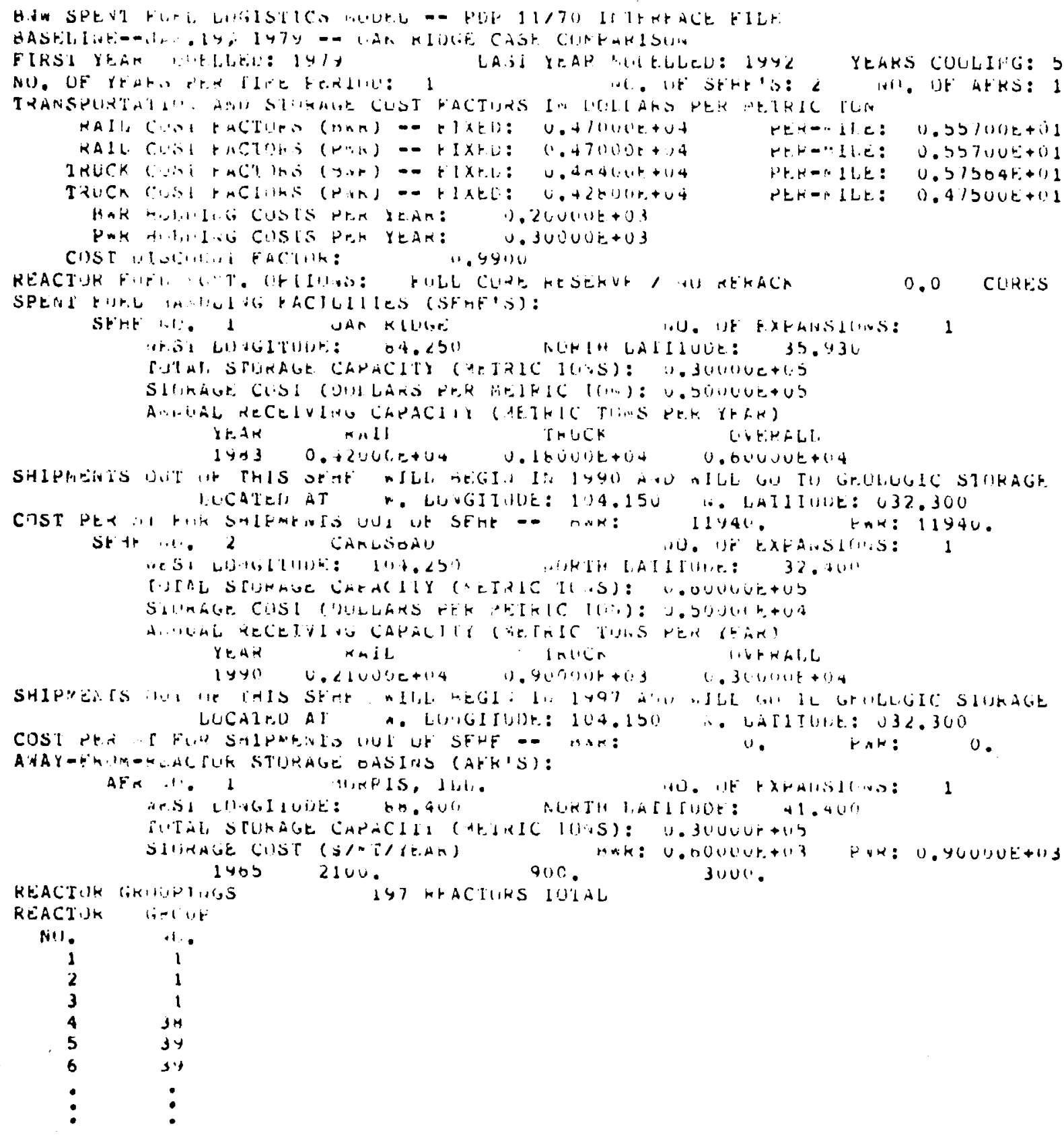

FIGURE B-1. Site Evaluation Model Input File 
HASELINE--JAN,19, 197Y - OAK RIDGE CASE COMPARISUN

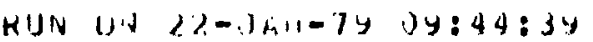

SHFII UNREPRUCESSEL HUEL SHIHMENT SUMMAKY

- - - - - - - - - - - - - - -

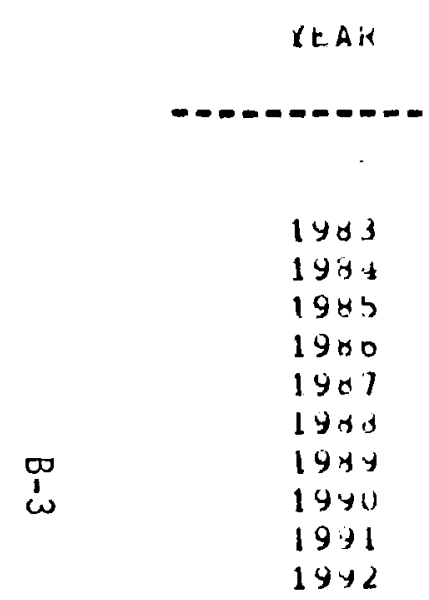

T:I'IALS

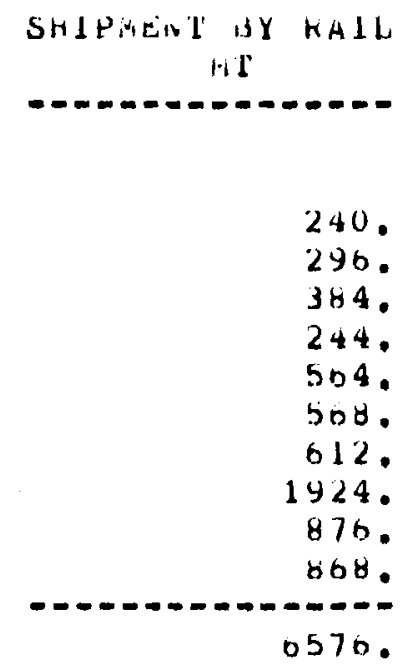

cust
siono

$---$

1858.

2177 .

2845.

2044 .

4418.

4191 .

4312 .

21916.

9310.

9704.

62694.

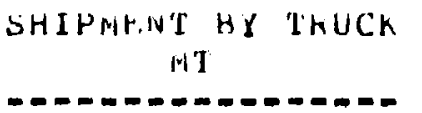

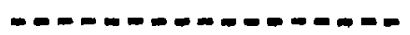

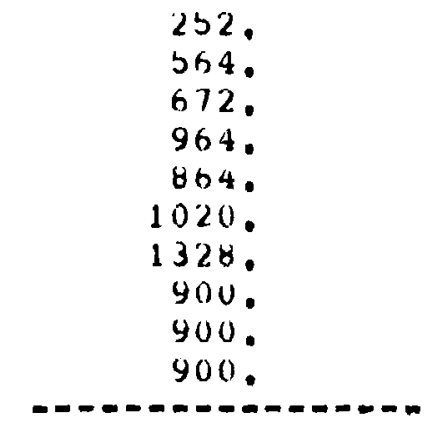

8364. cos'

$\$ 1000$

-.-

1895.

4119.

4846 .

6451.

6315.

7661 .

10011 .

10714.

10387 .

9622 .

$0-\infty$

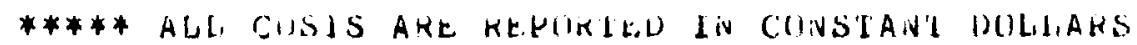
$(\rightarrow A S R$ YEAK 1 Y77)

FlGURE B-2. Spent Fuel Shipment Summary Report 
RUIN ON 22-JAir-7y U984483y

SFHF (SPENT FUEL HANDLING FACILITY)

SFHF LOCATIUN UAK HIDGE

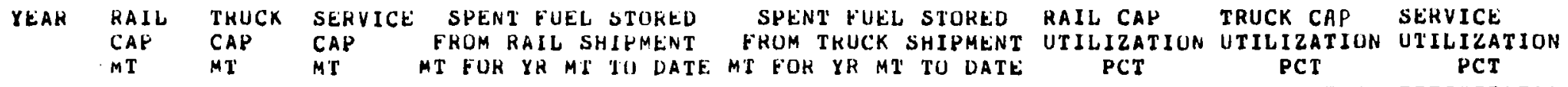

(n)

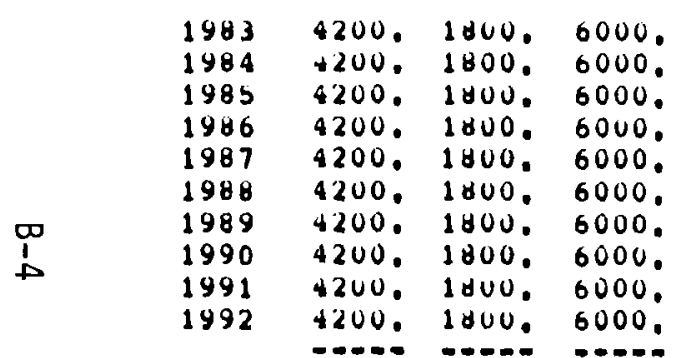

AVERAGE

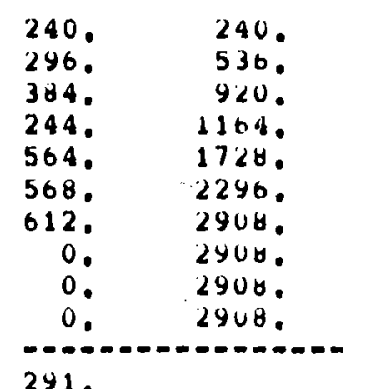

291 .

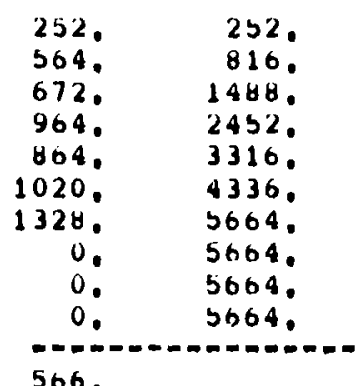

5.7143
7.0476
9.1429
5.8095
13.4286
13.5238
14.5714
0.0000
0.0000
0.0000
0.000
0.9238

14.0000

31.3333

37.3333

33.5550

48.0000

36.0667

73.7776

0.0000

0.0000

0,0000

31.9607

8.2000 14.3333

17.6000

20.1333

23,8000

26.4667

32.3333

0.0000

0.0000

5hb.

$6.923 \theta$

14.2867

FIGURE B-3. SFHF Report--0ak Ridge Site 
RUN UN 22-JAIN-79 09844839

$$
\text { SFHE (SPENT FUEL HANULING FACILITY) }
$$

SFHE (SPENT FUEL HANDLING FACILITY)

SFHF LOCATIUN CAKLSBAD

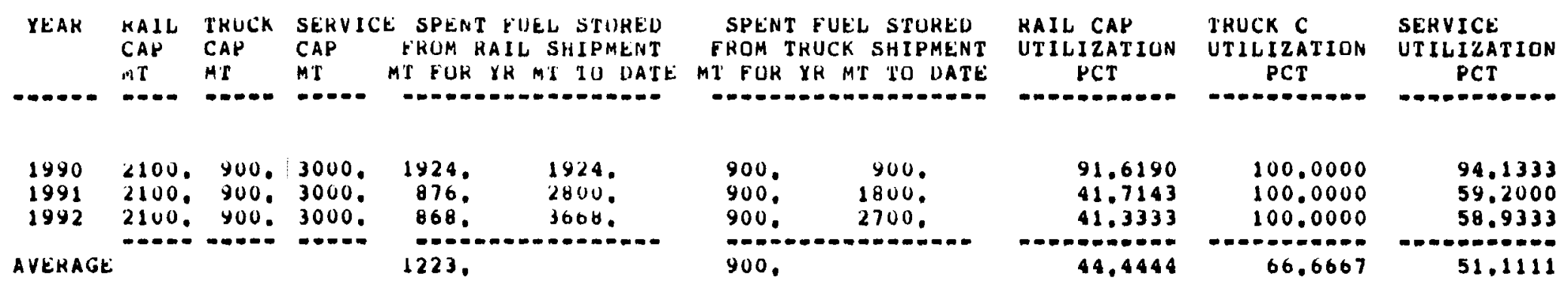


DASELINE-OJAIV.19, 197Y -- OAK NIUGE CASE COMPARISUN

Ruiv Ui 2z-Juli-7y $09: 44: 3 y$

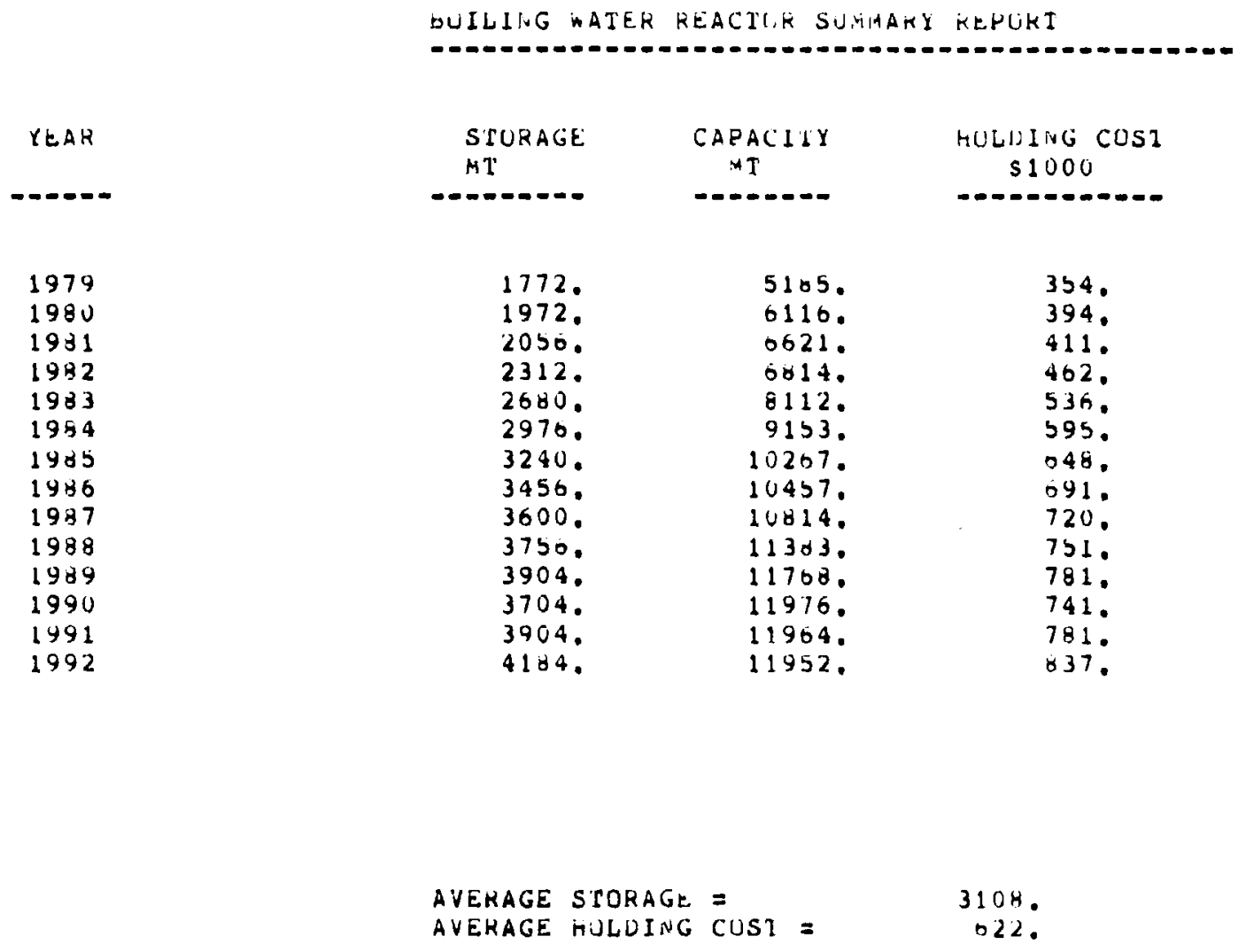

***** all cujis are repuried in coivstant dollars ( $B$ ASSE YEAR 1Y77)

FIGURE B-5. BWR On-Site Storage Summary Report 
OASELINE-JJAN.19, 197Y-- LAK RIUGE CASE CUMPARISUN RUN UN 22-,JA:J-7Y UY:44:39

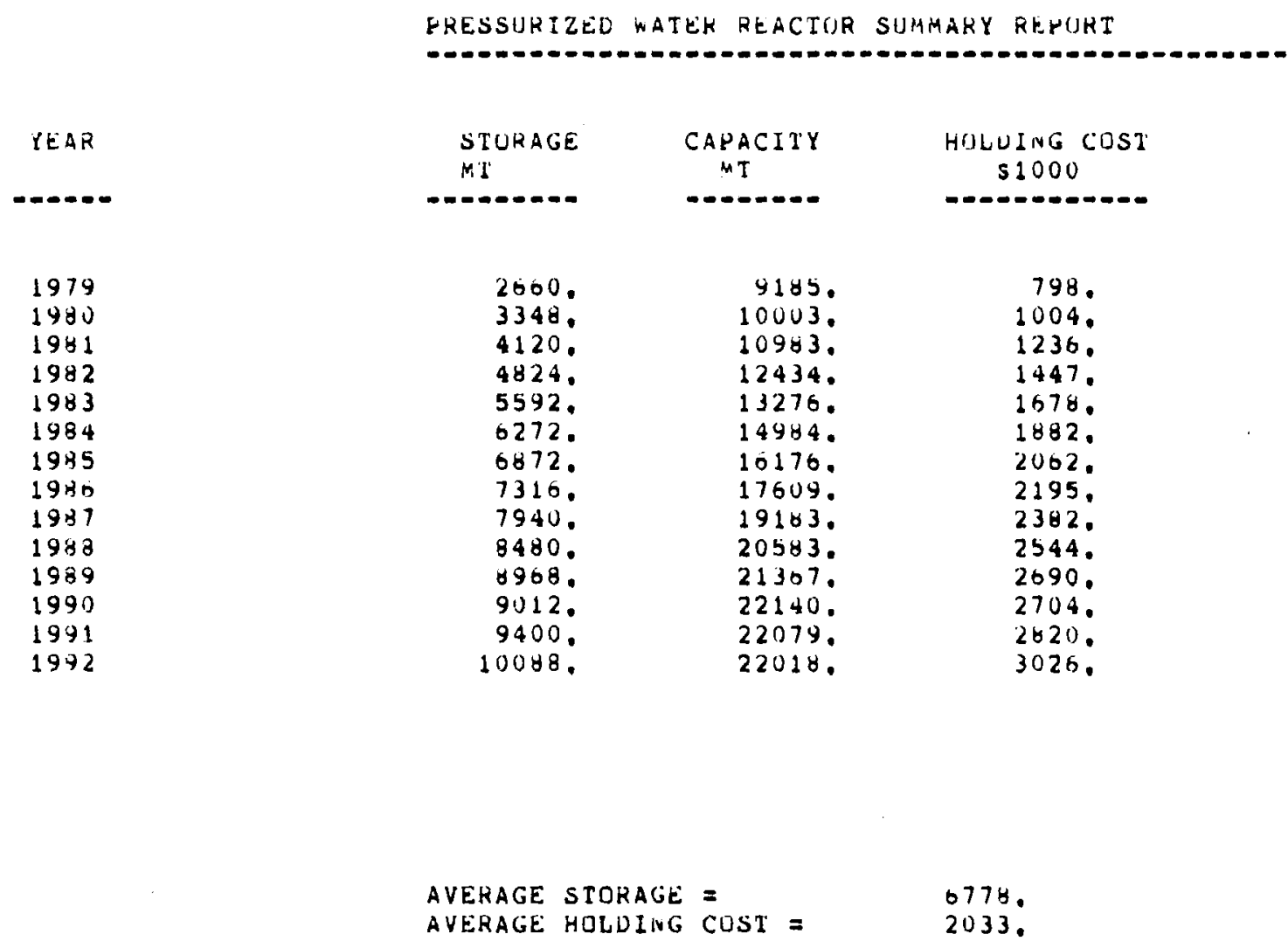

***** alL Costs ARE REPUHLEU IN CUNSTANT DOLLARS (BASE YEAK 1977)

FIGURE B-6. PWR On-Site Storage Summary Report 

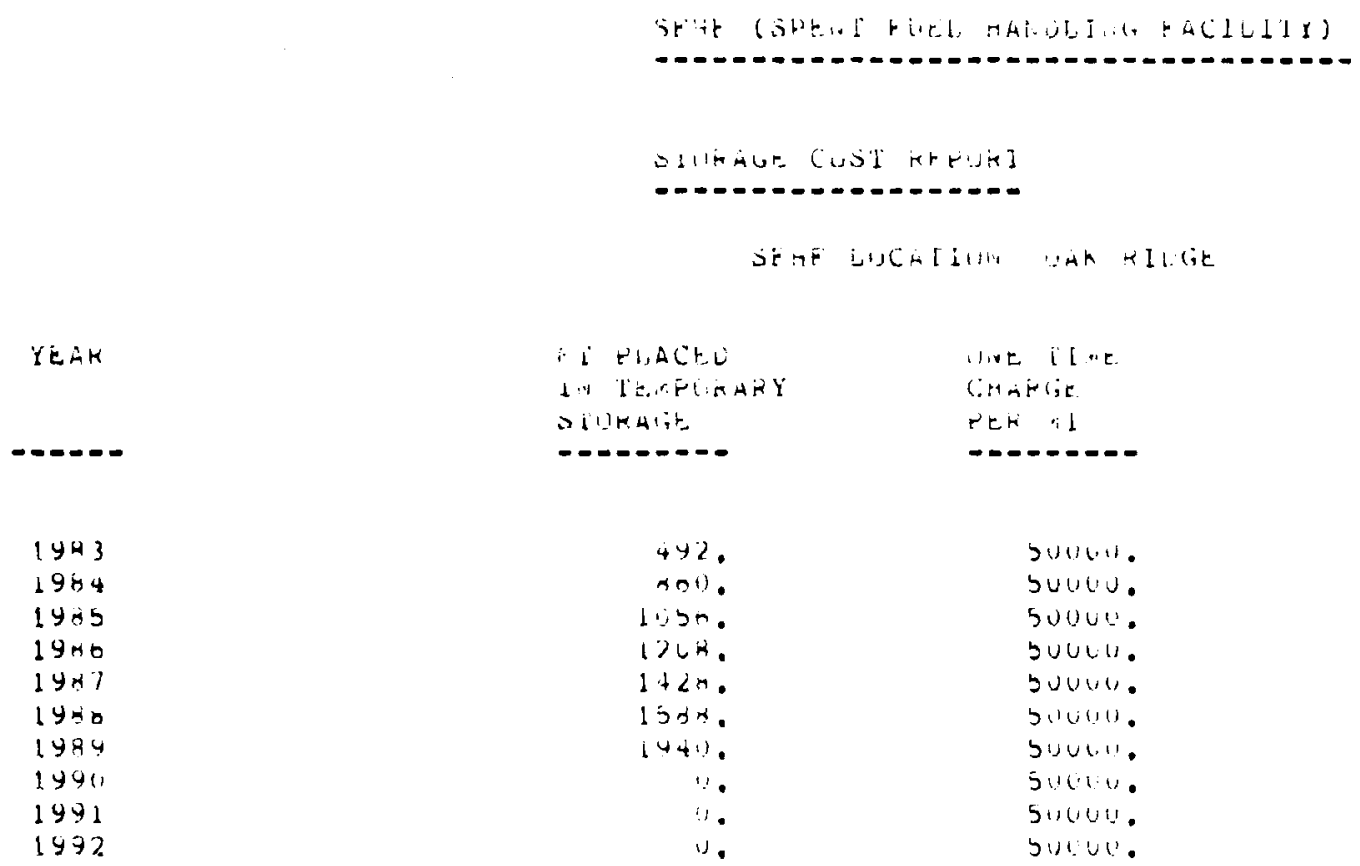

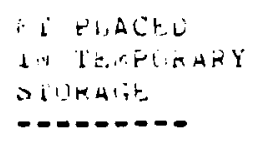

$-0-0--\infty$

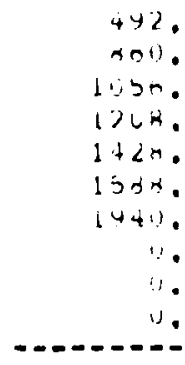

abl?.

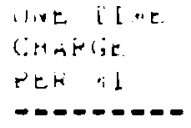

bUuth. suvive 500ue. รUบu⿺. buvwl. bivall. buvi.1. 501:0. 5nout. bus:ue.
IUIAL CUST S1) $10(1$

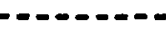

$24001 \%$ 43000 . 52800 . 50400 . 71000 . $79+40$. 37000 . i). j.

+2 ativo.

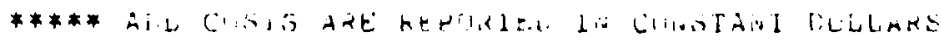
(1:S. Yr.hH $147 \%$ )

\section{FIGURE B-7. SFHF Storage Cost Report--Oak Ridge Site}




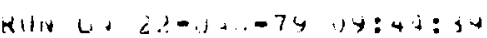
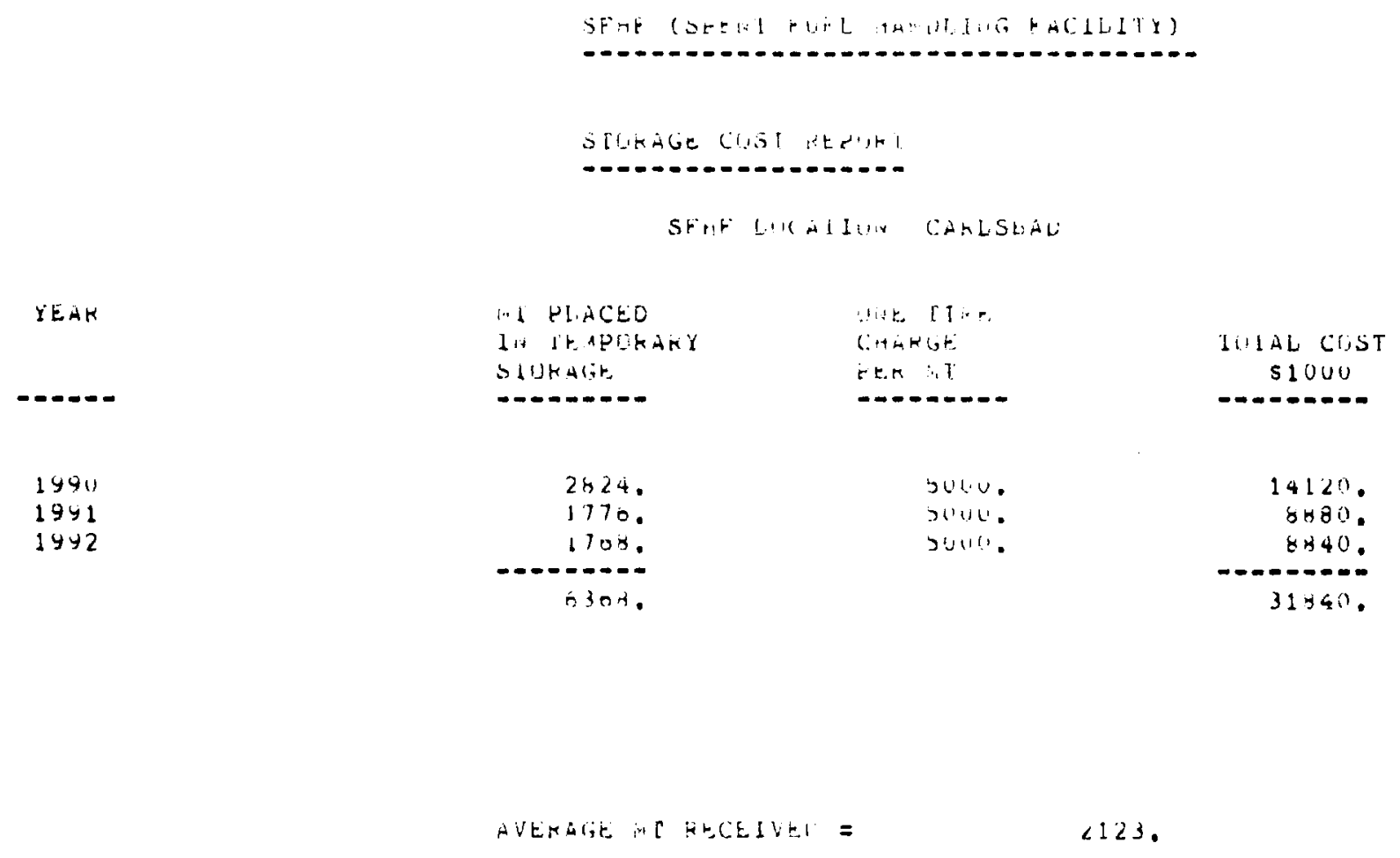

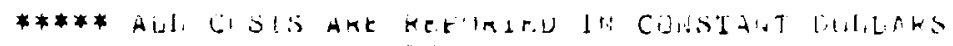
(थमStr. itAk $197 /$ )

FIGURE B-8. SFHF Storage Cost Report--Carlsbad Site 


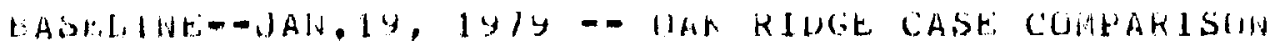

RUI U.V 2?-1A1!-7y Uy:44:31

SPEIVI FUEL HAHIMING FACIHITY

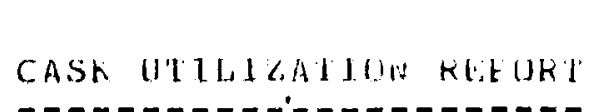

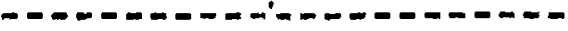

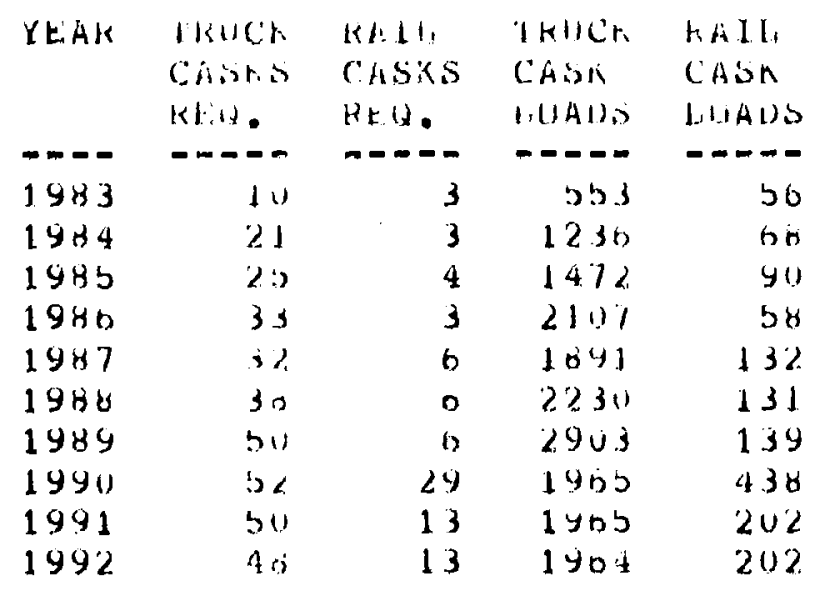

FIGURE B-9. Shipping Cask Utilization Report 
kulv un $22-1+1.79 \quad 19: 44: 39$

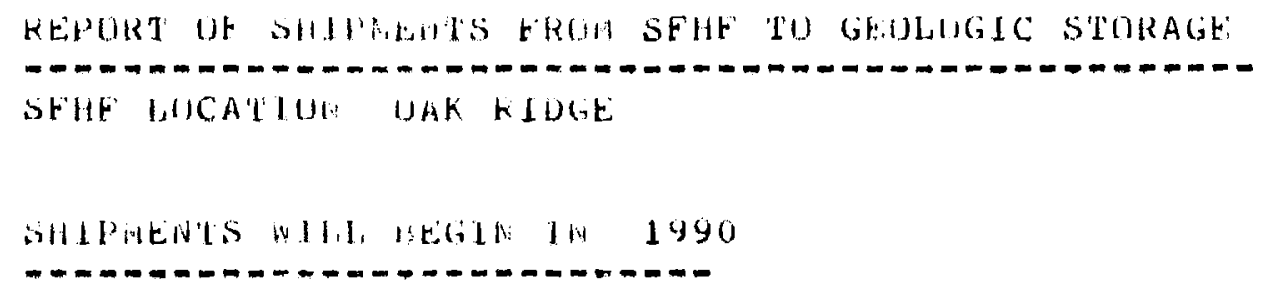


Ruiv U1, $22-1411-19$ 119:44:3y

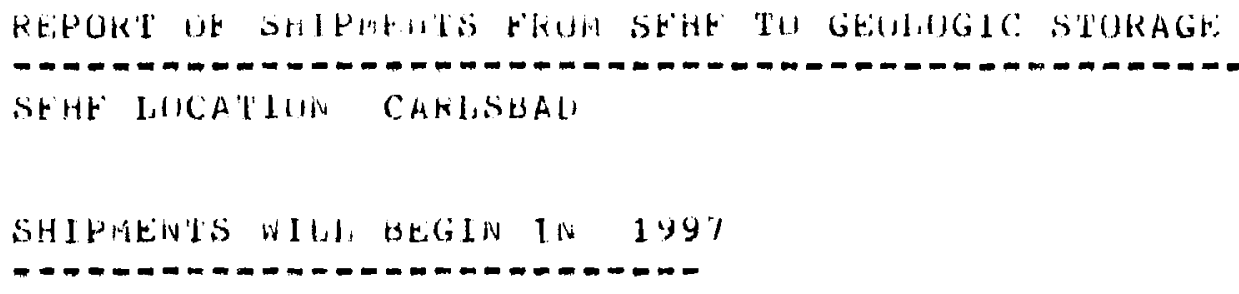

FIGURE B-11. Report of Shipments to Final Destination from Carlsbad SFHF 


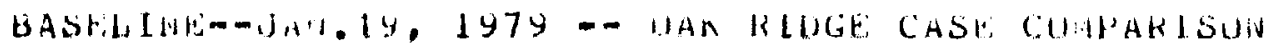

RINN UN 2\%-JAM-\% U9:44:39

AtK: M1IRKJis, LL

SURPI.YY

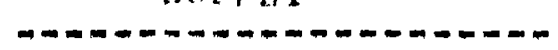

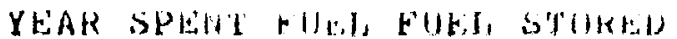
Al ArR (1'

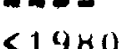

$<1960$

1380

1981

1982

1983

1984

1985

1986

1967

1988

1989

1990

1991

1942

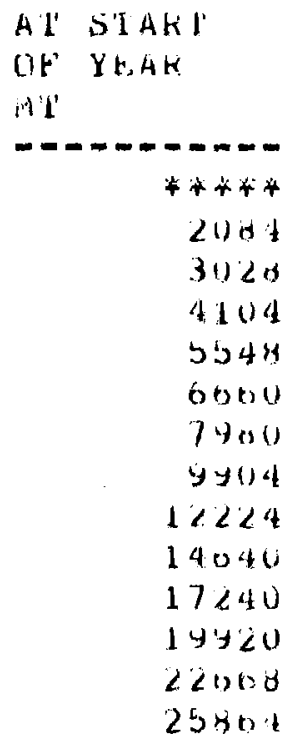

1) ISPUSI'I IIN

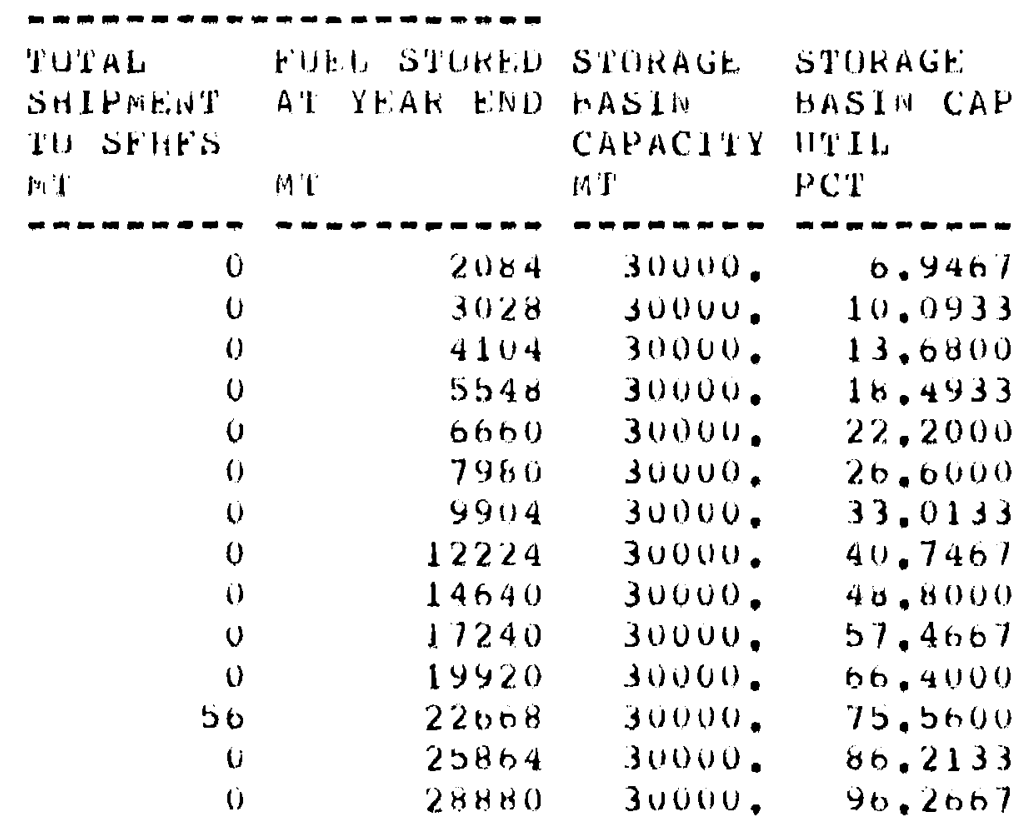

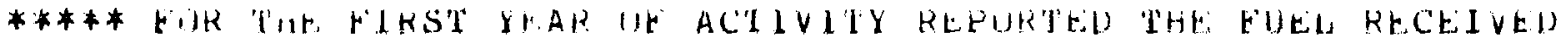

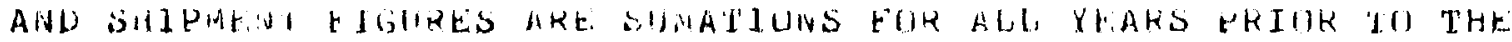

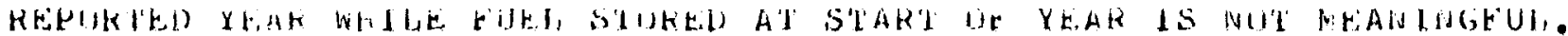

FIGURE B-12. AFR Shipment/Storage Summary Report 


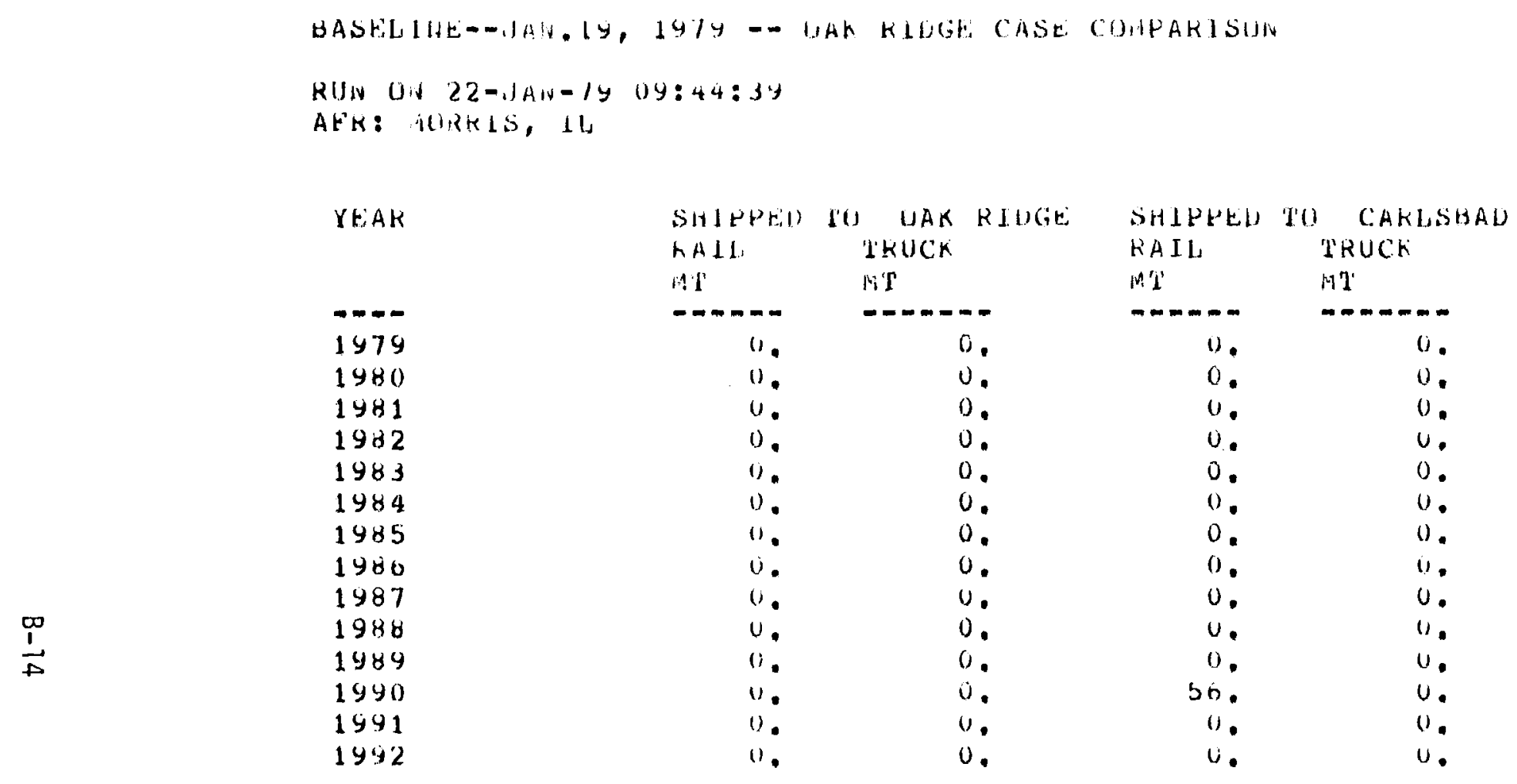

FIGURE B-13. Detailed AFR Shipment Report 


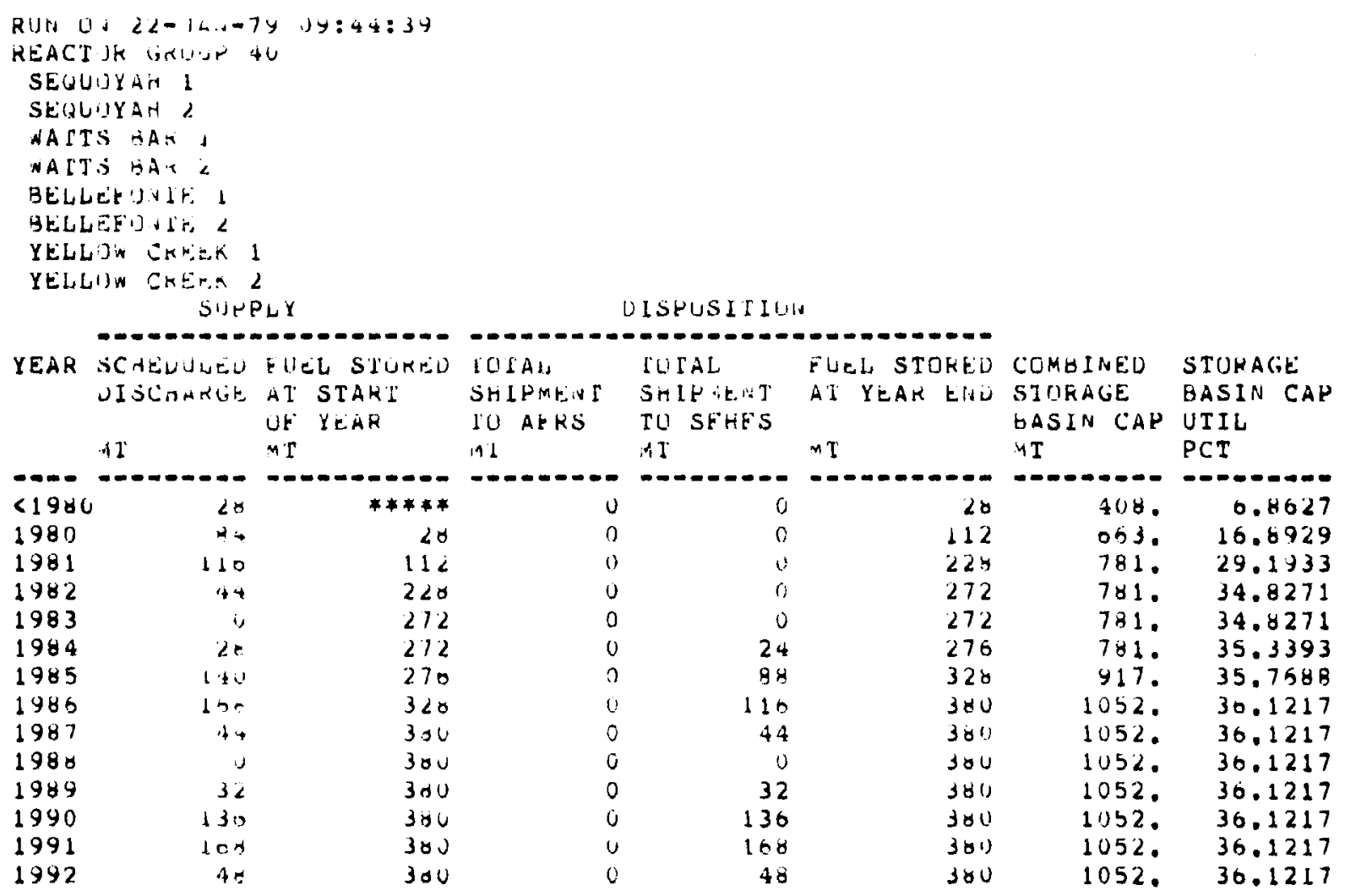

\#\#\#\#* FUR IrP. FIRSI YEAR UR ACTIVIVIY REPURIEU IHE DISCHARGE

AND SHIPEERI R IUURES ARE SUMATIUNS EOR ALL YEARS PKIOR TU THE

REPURTED IEAK YHILF THE FUEL SIURED AT SIART LF YEAK IS NOT MEANINGFUL.

FIGURE B-14. Reactor Group Summary Report--Group 40 


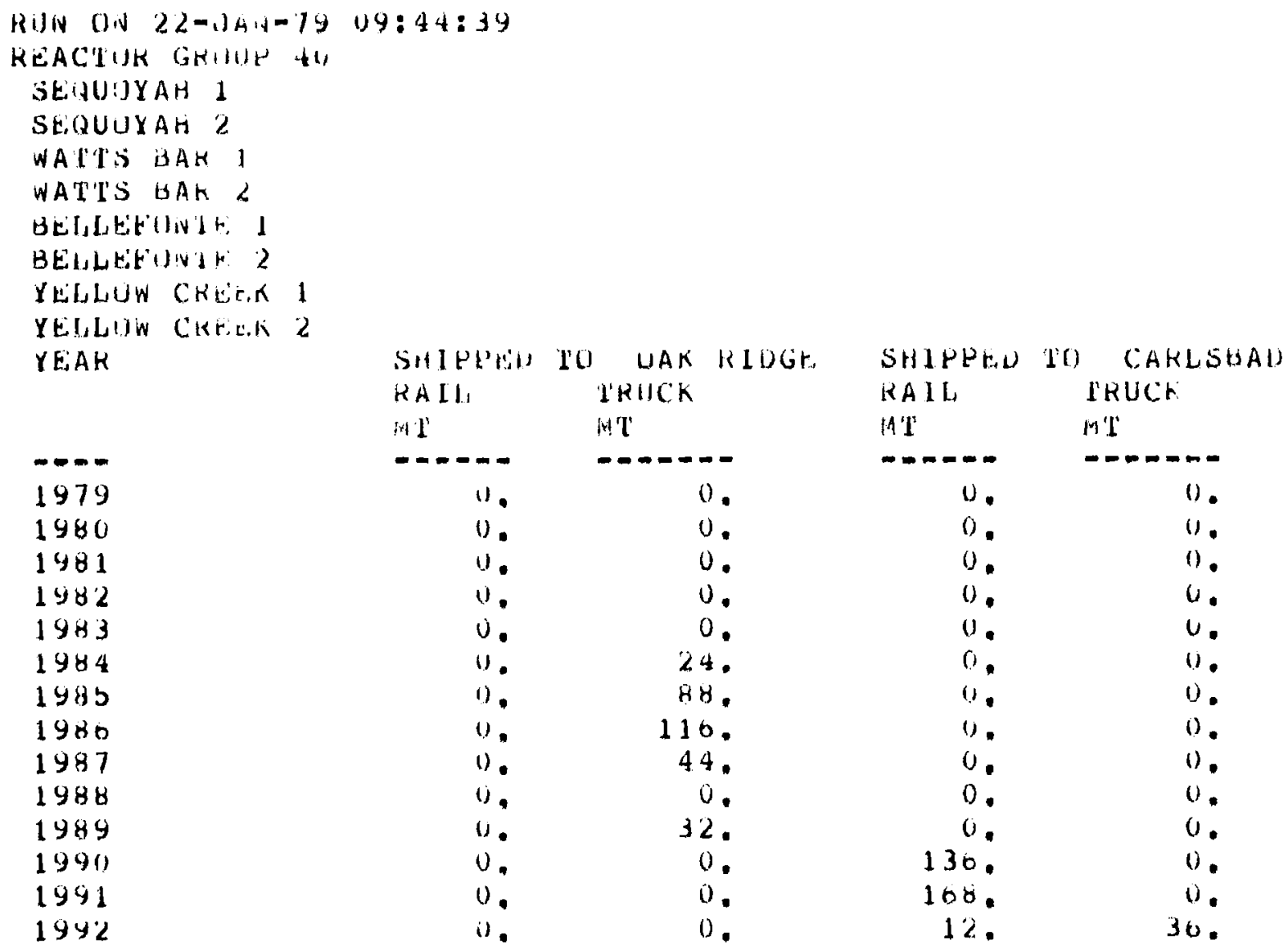

$\begin{array}{rr}0 . & 0 . \\ 0 & 0 . \\ 0 . & 0 . \\ 0 . & 0 . \\ 0 . & 0 . \\ 0 . & 0 . \\ 130 . & 0 . \\ 160 . & 0 . \\ 12 . & 0 .\end{array}$

FIGURE B-15. Detailed Reactor Group Shipment Report--Group 40 
APPENDIX C

LIST OF NUCLEAR POWER FACILITIES INCLUDED IN THE SITE EVALUATION MODEL DATA BASE 


\section{LIST OF NUCLEAR POWER FACILITIES INCLUDED IN}

THE SITE EVALUATION MODEL DATA BASE

The following list of nuclear power reactors from the Site Evaluation Model data base is based on the United States section of the World List of Nuclear Power Plants as published in the August 1978 issue of Nuclear News, pages 79-84. A currently operating, under construction, or proposed power plant is included in the data base only if it is a light water reactor design (Boiling Water Reactor--BWR or Pressurized Water Reactor--PWR) and its actual or expected year of startup is 1990 or earlier. Proposed plants with uncertain status or an indefinite startup date were not included. The list is arranged in order of actual or expected startup date. The reactor name, type, net MWe generating capacity, location (state and nearest town), and operating utility company are also included in the table. Other information in the data base for each reactor includes latitude and longitude, core size, on-site storage basin capacity, and actual or expected spent fuel discharge schedule (month/year and number of fuel assemblies for each scheduled discharge). 


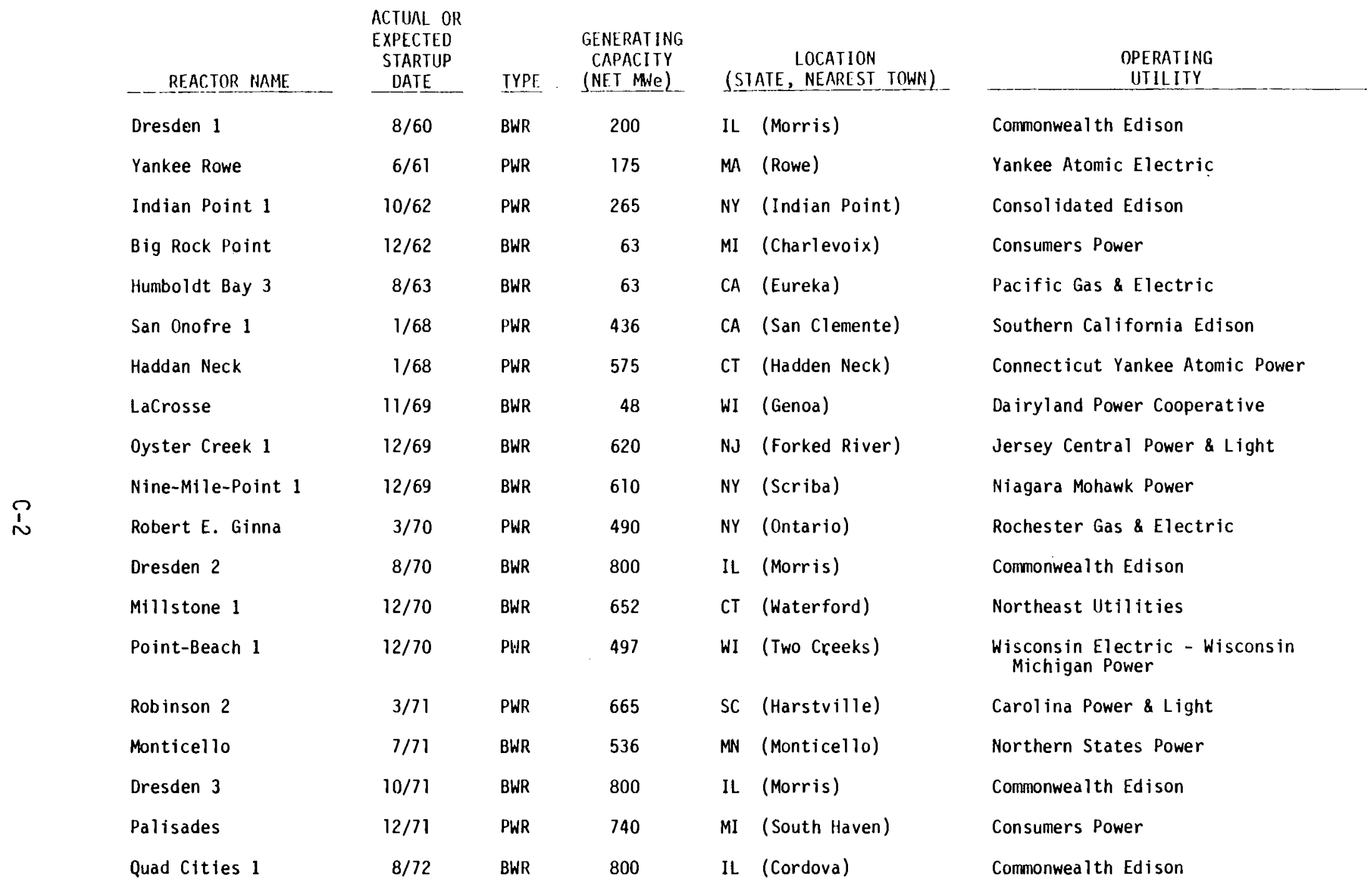




\begin{tabular}{|c|c|c|c|c|}
\hline REACTOR MAME. & $\begin{array}{c}\text { ACXUAL OR } \\
\text { EXECTED } \\
\text { STARTUP } \\
\text { DATE } \\
\end{array}$ & IYPE & $\begin{array}{l}\text { GENERATING } \\
\text { CAPACITY } \\
\text { (NET MWE) }\end{array}$ & $\begin{array}{l}\text { I.OCATION } \\
\text { (STATE, NEARESI TOWN) }\end{array}$ \\
\hline Quad Cities 2 & $10 / 72$ & BWR & 800 & IL (Cordova) \\
\hline Point-Beach 2 & $10 / 72$ & PWR & 497 & WI (Two Creeks) \\
\hline Vermont Yankee & $11 / 72$ & BWR & 514 & VT (Vernon) \\
\hline Maine Yankee & $12 / 72$ & PWR & 790 & ME (Wiscasset) \\
\hline Pilgrim 1 & $12 / 72$ & BWR & 670 & MA (Plymouth) \\
\hline Surry 1 & $12 / 72$ & PWR & 775 & VA (Gravel Neck) \\
\hline Turkey Point 3 & $12 / 72$ & PWR & 666 & $\mathrm{FL}$ (Florida City) \\
\hline Surry 2 & $5 / 73$ & PWR & 775 & VA (Gravel Neck) \\
\hline Zion 1 & $6 / 73$ & PWR & 1100 & IL (Zion) \\
\hline Oconee 1 & $7 / 73$ & PWR & 860 & SC (Seneca) \\
\hline Fort Calhoun 1 & $9 / 73$ & PWR & 457 & NE (Fort Calhoun) \\
\hline Turkey Point 4 & $9 / 73$ & PWR & 666 & $\mathrm{FL}$ (Florida City) \\
\hline Zion 2 & $12 / 73$ & PWR & 1100 & IL (Zion) \\
\hline Prairie Island 1 & $12 / 73$ & PWR & 520 & MN (Red Wing) \\
\hline Duane Arnold & $5 / 74$ & BWR & 545 & IA (Palo) \\
\hline Kewaunee & $6 / 74$ & PWR & 535 & WI (Carlton) \\
\hline Cooper & $7 / 74$ & BWR & 778 & NE (Brownville) \\
\hline Peach Bottom 2 & $7 / 74$ & BWR & 1065 & PA (Peach Bottom) \\
\hline Indian Point 2 & $7 / 74$ & PWR & 873 & NY (Indian Point) \\
\hline
\end{tabular}

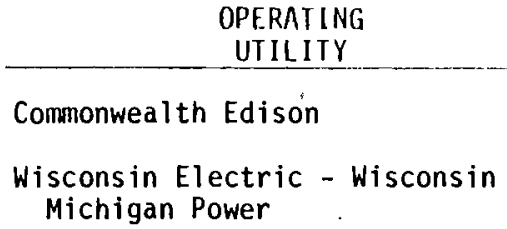

Commonwealth Edison

Wisconsin Electric - Wisconsin Michigan Power

Vermont Yankee Nuclear Power

Maine Yankee Atomic Power

Boston Edison

Virginia Electric \& Power

Florida Power \& Light

Virginia Electric \& Power

Commonwealth Edison

Duke Power

Omaha Public Power District

Florida Power \& Light

Commonwealth Edison

Northern States Power

Iowa Electric Light \& Power

Wisconsin Public Service

Nebraska Public Power District

Philadelphia Electric

Consolidated Edison 


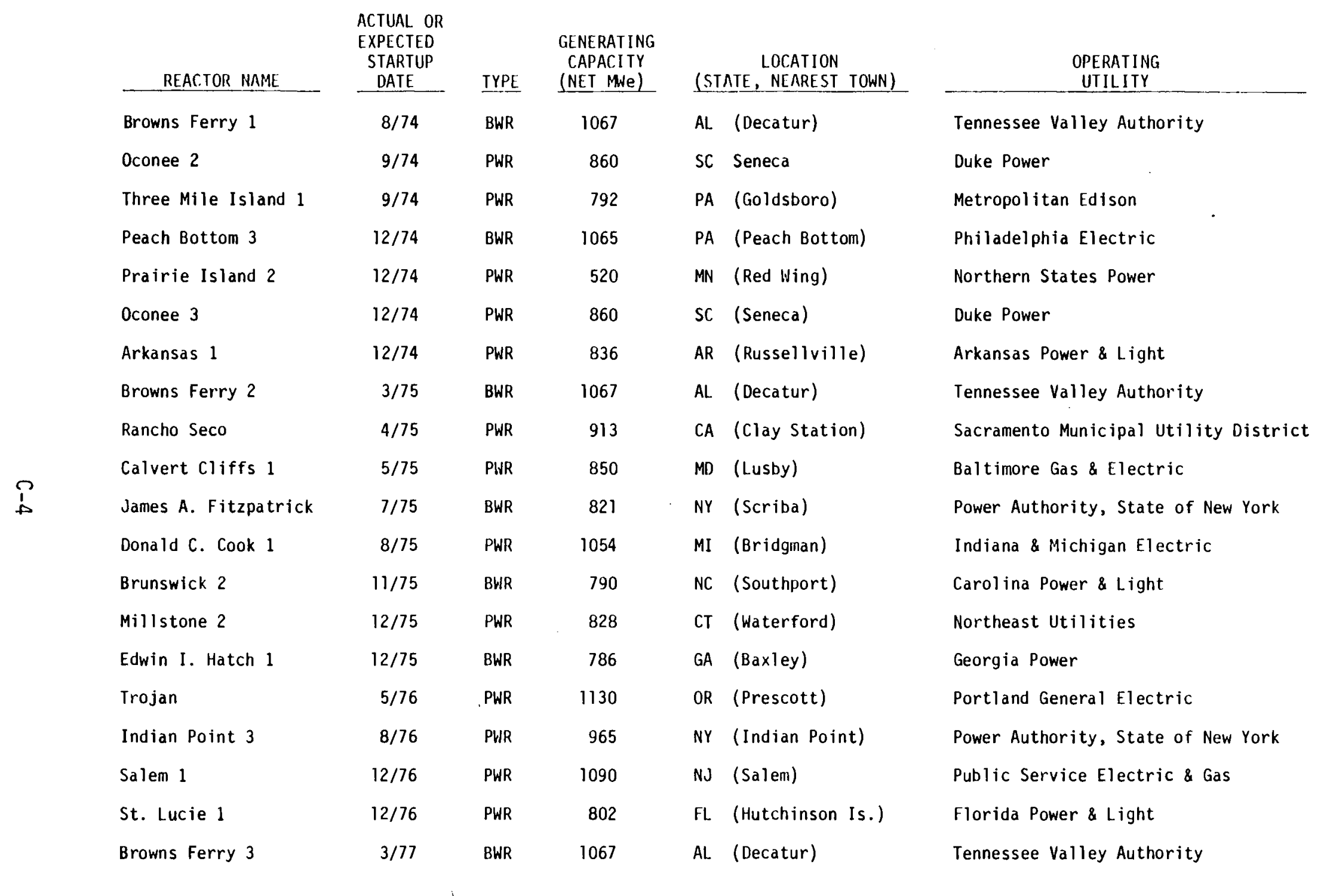




\begin{tabular}{|c|c|c|c|c|c|}
\hline REACTOR NAME & $\begin{array}{l}\text { ACTUAL OR } \\
\text { EXPECTED } \\
\text { STARTUP } \\
\text { DATE } \\
\end{array}$ & TYPE & $\begin{array}{l}\text { GENERATING } \\
\text { CAPACITY } \\
\text { (NET MNE) }\end{array}$ & $\begin{array}{l}\text { LOCATION } \\
\text { (STATE, NEAREST TOWN) }\end{array}$ & $\begin{array}{l}\text { OPERATING } \\
\text { UTILITY }\end{array}$ \\
\hline Crystal River 3 & $3 / 77$ & PWR. & 825 & FL (Red Level) & Florida Power Corporation \\
\hline Brunswick 1 & $3 / 77$ & BWR & 790 & NC (Southport) & Carolina Power \& Light \\
\hline Beaver Valley 1 & $4 / 77$ & PWR & 833 & PA (Shippingport) & Duquesne Light \\
\hline Calvert $\mathrm{Cl}$ iffs 2 & $4 / 77$ & PWR & 850 & MD (Lusby) & Baltimore Gas \& Electric \\
\hline Davis-Besse 1 & $11 / 77$ & PWR & 906 & $\mathrm{OH}$ (Oak Harbor) & Toledo Edison \\
\hline Joseph M. Farley 1 & $12 / 77$ & PWR & 860 & AL (Dothan) & Alabama Power \\
\hline North Anna 1 & $6 / 78$ & PWR & 934 & VA (Mineral) & Virginia Electric \& Power \\
\hline Donald C. Cook 2 & $6 / 78$ & PWR & 1094 & MI (Bridginan) & Indiana \& Michigan Electric \\
\hline Edwin I. Hatch 2 & $11 / 78$ & BWR & 786 & GA (Baxley) & Georgia Power \\
\hline Three Mile Island 2 & $11 / 78$ & PWR & 880 & PA (Goldsboro) & Metropolitan Edison \\
\hline Diablo Canyon 1 & $11 / 78$ & PWR & 1060 & CA (Diablo Canyon) & Pacific Gas \& Electric \\
\hline Arkansas 2 & $12 / 78$ & PWR & 912 & AR (Russellville) & Arkansas Power \& Light \\
\hline North Anrla 2 & $4 / 79$ & PWR & 934 & VA (Mineral) & Virginia Electric \& Power \\
\hline Salem 2 & $5 / 79$ & PWR & 1115 & NJ (Salem) & Public Service Electric \& Gas \\
\hline Diablo Canyon 2 & $5 / 79$ & PWR & 1060 & CA (Diablo Canyon) & Pacific Gas \& Electric \\
\hline McGuire 1 & $7 / 79$ & PWR & 1180 & NC (Terrell) & Duke Power \\
\hline Sequoyah 1 & $7 / 79$ & PWR & 1148 & IN (Daisy) & Tennessee Valley Authority \\
\hline LaSalle 1 & $9 / 79$ & BWR & 1078 & IL (Seneca) & Commonwealth Edison \\
\hline Watts Bar 1 & $12 / 79$ & PWR & 1177 & IN (Spring City) & Tennessee Valley Authority \\
\hline
\end{tabular}




\begin{tabular}{|c|c|c|c|c|c|}
\hline REACTOR NAME & $\begin{array}{l}\text { ACTUAL OR } \\
\text { EXPECTED } \\
\text { STARTUP } \\
\text { DATE } \\
\end{array}$ & $\underline{\text { TYPF. }}$ & $\begin{array}{l}\text { GENERATING } \\
\text { CAPACI TY } \\
\text { (NET MWe) } \\
\end{array}$ & $\begin{array}{l}\text { LOCATION } \\
\text { (STAIE, NEAREST TOWN) }\end{array}$ & $\begin{array}{c}\text { OPERATING } \\
\text { UTILIIY }\end{array}$ \\
\hline Zimmer 1 & $/ 79$ & BWR & 810 & OH (Moscow) & Cincinnati Gas \& Electric \\
\hline Sequoyah 2 & $3 / 80$ & PWR & 1148 & TN (Daisy) & Tennessee Valley Authority \\
\hline Virgil c. Summer 1 & $5 / 80$ & PWR & 900 & SC (Parr) & South Carolina Electric \& Gas \\
\hline Bellefonte 1 & $6 / 80$ & PWR & 1213 & AL (Scottsboro) & Tennessee Valley Authority \\
\hline Watts Bar 2 & $9 / 80$ & PWR & 1177 & TN (Spring City) & Tennessee Valley Authority \\
\hline LaSalle 2 & $9 / 80$ & BWR & 1078 & IL (Seneca) & Commonwealth Edison \\
\hline WNP-2 & $9 / 80$ & BWR & 1100 & WA (Richland) & Washington Public Power Supply System \\
\hline South Texas 1 & $10 / 80$ & PWR & 1250 & TX (Palacios) & Houston Lighting \& Power \\
\hline San Onofre 2 & $10 / 80$ & PWR & 1057 & CA (San Clemente) & Southern California Edison \\
\hline Joseph M. Farley 2 & $/ 80$ & PWR & 860 & AL (Dothan) & Alabama Power \\
\hline Fermi 2 & $/ 80$ & BWR & 1100 & MI (Newport) & Detroit Edison \\
\hline Shoreham & 180 & BWR & 820 & NY (Brookhaven) & Long Island Lighting \\
\hline Comanche Peak 1 & $1 / 81$ & PWR & 1150 & TX (Glen Rose) & Texas Utilities \\
\hline Susquehanna 1 & $2 / 81$ & BWR & 1050 & PA (Berwick) & Pennsylvania Power \& Light \\
\hline Midland 2 & $3 / 81$ & PWR & 805 & MI (Midland) & Consumers Power \\
\hline Bellefonte 2 & $3 / 81$ & PWR & 1213 & AL (Scottsboro) & Tennessee Valley Authority \\
\hline McGuire 2 & $3 / 81$ & PWR & 1180 & NC (Terrell) & Duke Power \\
\hline Waterford 3 & $4 / 81$ & PWR & 1165 & LA (Taft) & Louisiana Power \& Light \\
\hline Grand Gulf 1 & $4 / 81$ & BWR & 1250 & MS (Port Gibson) & Mississippi Power \& Light \\
\hline
\end{tabular}




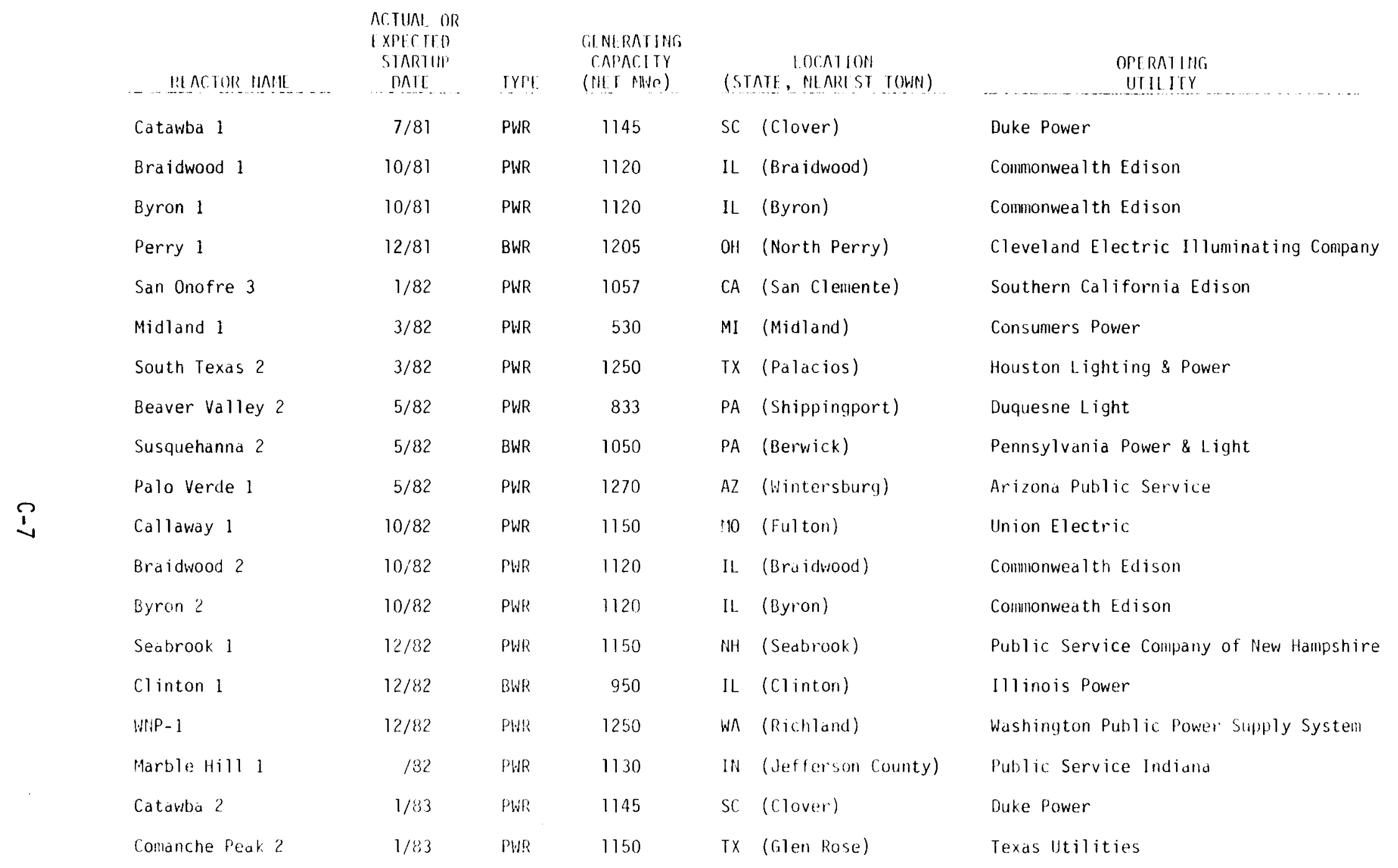




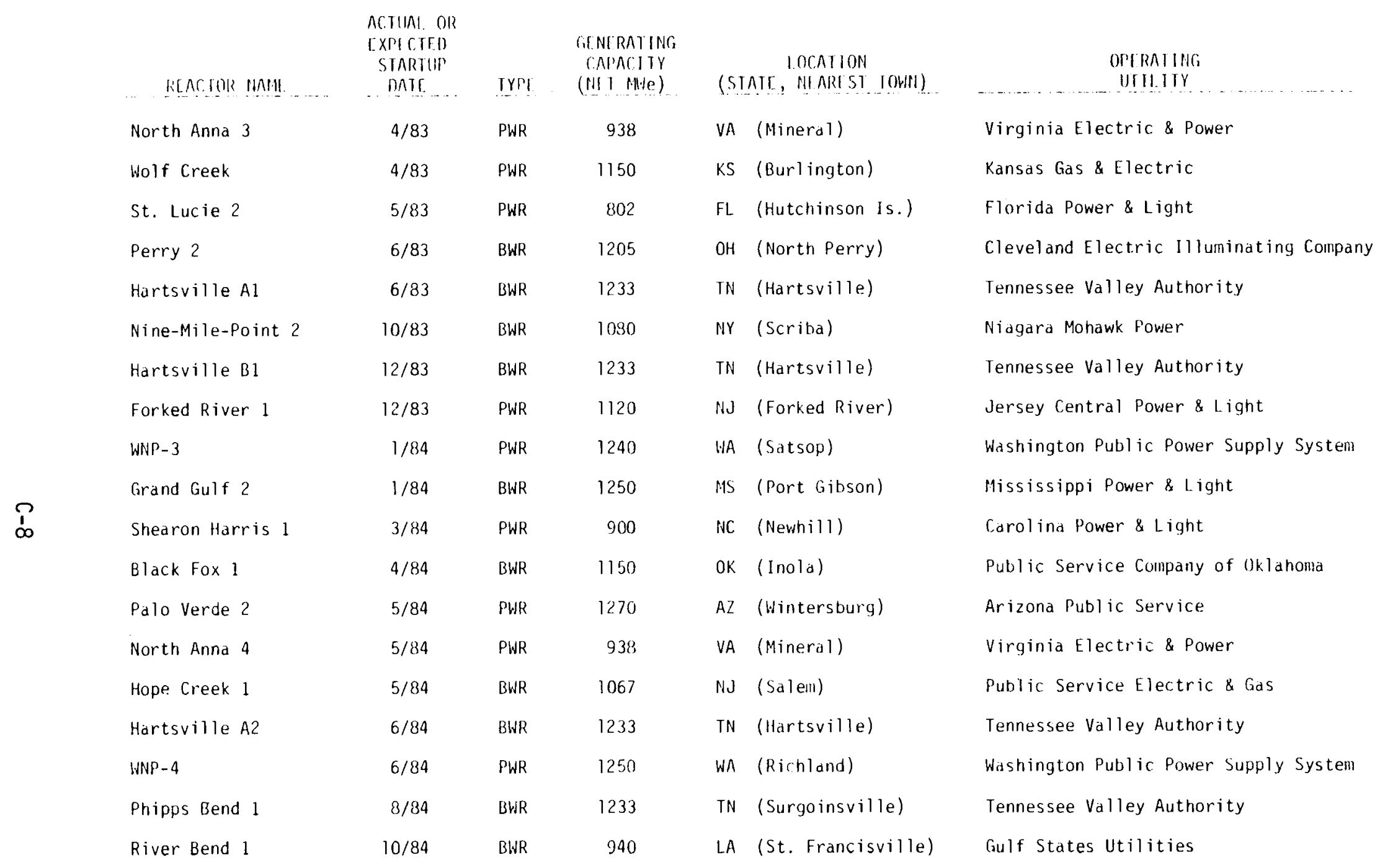




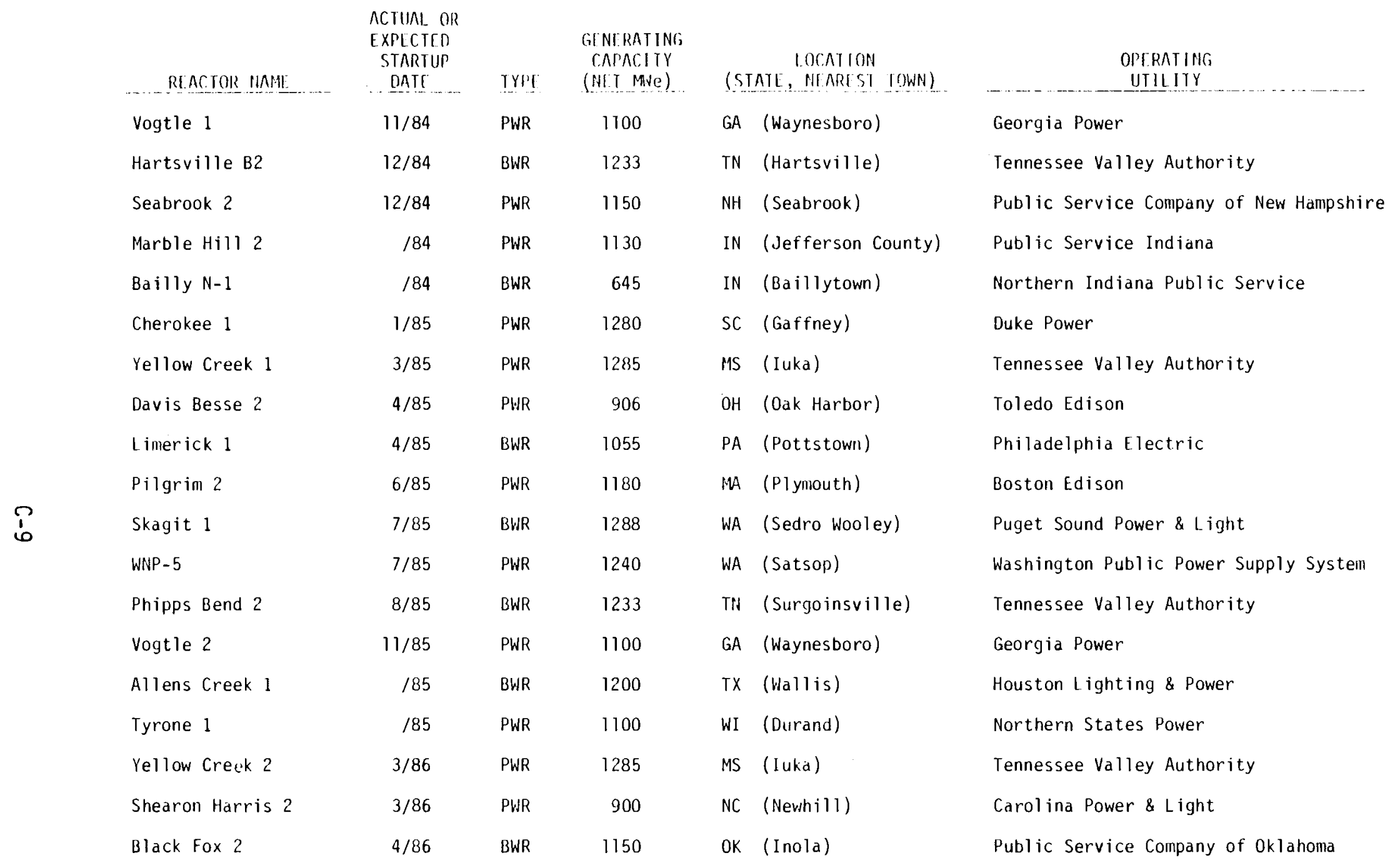




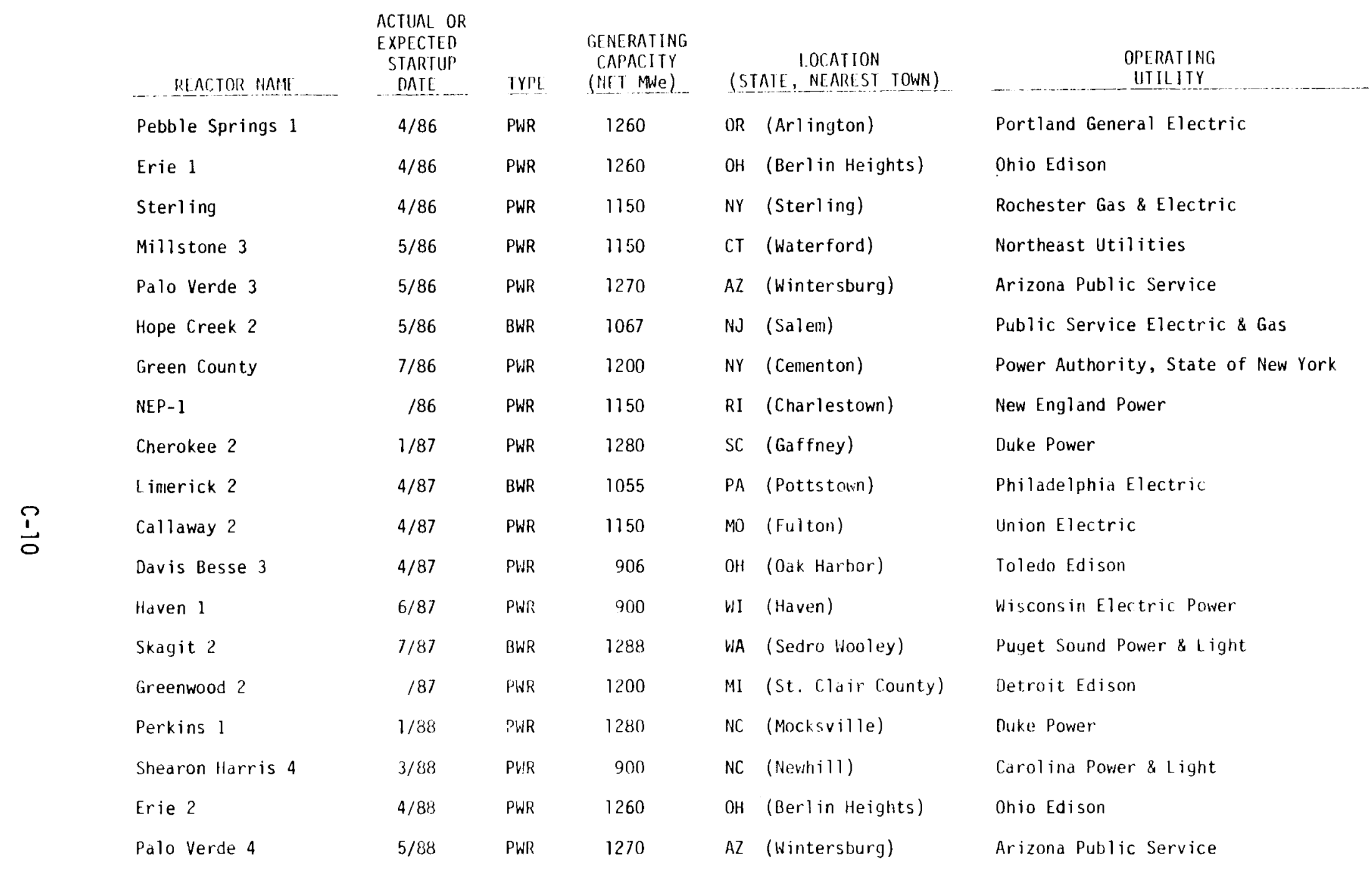




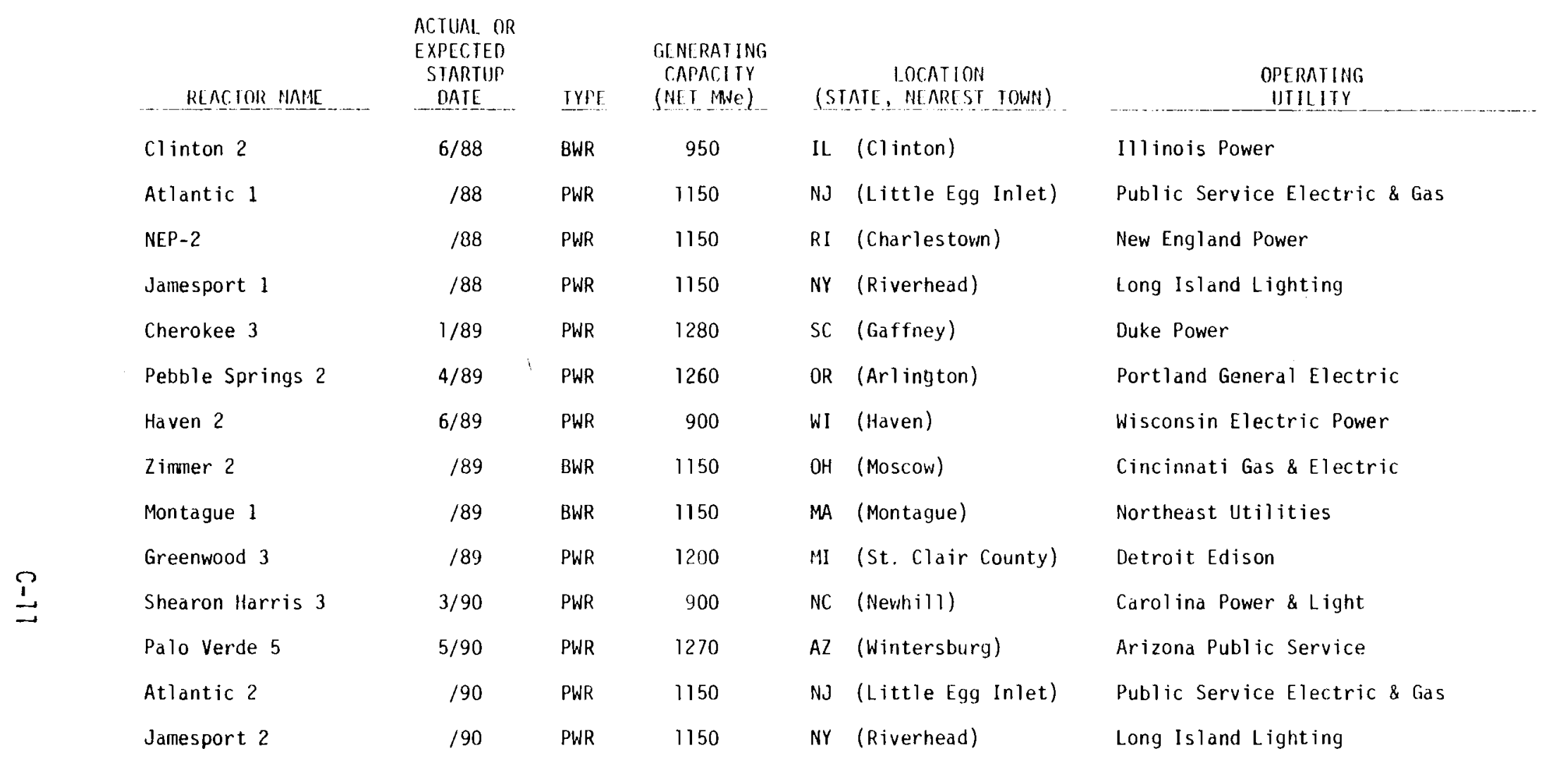





\section{DISTRIBUTION}

No. of

Copies

OFFSITE

A. A. Churm

Chicago Patent Group

DOE Chicago Operations Office

9800 South Cass Avenue

Argonne, IL 60439

27 DOE Technical Information Center

J. A. Sisler

Division of Transportation and Fuel Storage

Department of Energy

Washington, DC 20545

R. B. Chitwood

Division of Transportation and Fuel Storage

Department of Energy

Washington, DC 20545

E. C. Hardin, Jr.

DOE Albuquerque Operations Office

P.0. Box 5400

A7buquerque, NM 87115

C. R. Cooley

U.S. Department of Energy Headquarters

Washington, DC 20545

C. A. Heath

U.S. Department of Energy Headquarters

Washington, DC 20545

J. B. Work

U.S. Department of Energy Headquarters

Washington, DC 20545
No. of

Copies

2 A. J. Roberts

U.S. Department of Energy

Nevada Operations Office

P.0. Box 435

Mercury, NV 89023

F. L. Harris

Kaiser Engineers, Inc.

300 Lakeside Drive

P.0. Box 23210

Oakland, CA 94666

4 Office of Nuclear Waste Isolation

Battelle Project Management Division

S. J. Basham

J. A. Carr (3)

Battelle Memorial Institute

Office of Nuclear Waste

Isolation

Attn: Beverly Rawles

505 King Avenue

Columbus, $\mathrm{OH} 43201$

Susan Metzler

System Communications

N. E. Utilities

P.0. Box 270

Hartford, CT 06101

R. L. Ferguson

Director, Nuclear Energy

Programs

Department of Energy

Washington, DC 20545

T. A. Butler

University of California

Los Alamos Scientific Laboratory

P.0. Box 1663

Los Alamos, NM 87545 
No. of

Copies

L. Benner

National Transportation

Safety Board

Department of Transportation

Washington, DC 20594

A. L. Schmieg

National Transportation

Safety Board

Department of Transportation

Washington, DC 20594

L. D. Santman

Materials Transportation Bureau

Department of Transportation

2100 Second St. S.W.

Washington, DC 20590

Dr. H. C. Thompson

Battelle Memorial Institute

Washington Operations

20301 M St. N.W.

Washington, DC 20036

C. Starr

Electrical Power Research Inst.

P.0. Box 10412

Palo Alto, CA 94304

C. Comar

Electrical Power Research Inst.

P.0. Box 10412

Palo Alto, CA 94304

E. Zebrowski

Electrical Power Research Inst.

P.0. Box 10412

Palo Alto, CA 94304

R. Williams

Electrical Power Research Inst.

P.0. Box 10412

Palo Alto, CA 94304

J. Freedman

Sandia Laboratories

P.0. Box 5800

Aibuquerque, NM 87115
No. of

Copies

R. M. Jefferson

Sandia Laboratories

P.0. Box 5800

Albuquerque, NM 87115

R. Luna

Sandia Laboratories

P.0. Box 5800

Albuquerque, NM 87115

R. B. Pope

Sandia Laboratories

P.0. Box 5800

Albuquerque, NM 87115

G. Allen

Sandia Laboratories

P.0. Box 5800

Albuquerque, NM 87115

D. S. Joy

Union Carbide Corporation

Oak Ridge National Laboratory

P.0. Box $X$

Oak Ridge, TN 37830

L. Shappert

Union Carbide Corporation

Oak Ridge National Laboratories

P.0. Box X

Oak Ridge, TN 37830

J. R. Marshall

Union Carbide Corporation

Oak Ridge National Laboratory

P.0. Box $X$

Oak Ridge, TN 37830

J. S. Corbett

ChemNuclear Sys tems, Inc.

P.0. Box 1866

Bellevue, WA 98009

D. A. Edling

Mound Laboratories

P.0. Box 32

Miamisburg, $\mathrm{OH} 45342$ 
No. of

Copies

J. Walker

Cal ifornia Energy Resources

Conservation and Development Commission

1111 Howe Avenue

Sacramento, CA 95825

B. Jost

Mail Stop 18

California Energy Resources

Conservation and Development Commission

1111 Howe Avenue

Sacramento, CA 95825

R. H. Jones

Transportation Systems

Nuclear Energy Programs

Division

General Electric Company

175 Curtner Avenue

San Jose, CA 95125

M. Gordon

Atomic Industrial Forum

7101 Wisconsin Avenue

Washington, DC 20014

A. L. Babb

Department of Nuclear Engineering

Benson Hall

University of Washington

Seattle, WA 98195

R. W. Peterson

Battelle Memorial Institute

Office of Nuclear Waste

Isolation

505 King Avenue

Columbus, $\mathrm{OH} 43201$

G. Waymire

Exxon Nuclear Company, Inc.

P.0. Box 3990

MS $8 A-68$

Seattle, WA 98124
No. of

Copies

C. A. Mayer

Tri-State Motor Transit

Co., Inc.

P.0. Box 113

Joplin, MO 64801

J. Edlow

Edlow International

110017 th Street N.W.

Washington, DC 20036

R. R. Raw 1

Materials Transportation Bureau

U.S. Department of Transportation

Washington, DC 20545

M. M. Heiskel

Union Carbide Corporation

Oak Ridge National Laboratory

P.O. Box $X$

Oak Ridge, TN 37830

ONSITE

7 DOE Richland Operations Office

J. M. Peterson

H. E. Ransom

J. J. Schreiber (2)

J. Neff (3)

15 Rockwell Hanford Company

W. B. Bevan

W. M. Harty

W. J. Kurzeka

E. L. Moore

R. E. Smith (10)

D. D. Woodrich

3 United Nuclear Industries, Inc.

J. A. Adams

P. A. Crosetti

T. E. Dabrowski 
No. of

Copies

2 Washington Public Power Supply System

G. F. Bailey

J. B. Vetrano

4 Hanford Engineering Development Laboratory

A. W. DeMerschman

D. A. Cantley (3)

63 Pacific Northwest Laboratory

W. B. Andrews

J. C. Bower

R. A. Burnett (10)

N. M. Burleigh (25)

J. G. DeSteese

H. K. Elder

R. L. Engel

R. M. Fleischman

A. L. Franklin

C. A. Geffen

J. Greenborg

M. R. Kreiter

J. W. Litchfield

R. C. Liikala

E. S. Murphy

A. M. Platt

R. E. Rhoads

C. W. Rolland

J. J. Thomas

J. W. Voss

R. D. Widrig

L. D. Wili iams

W. K. Winegardner

Technical Information (5)

Publishing Coordination (2) 